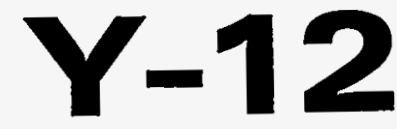

\section{OAK FIDGE $\mathrm{Y}-12$ PLANT}

MARTIN MARUETRA

MANAGED BY

MARTIN MARIETTA ENERGY SYSTEMS, INC.

FOR THE UNITED STATES DEPARTMENT OF ENERGY
EVALUATION OF CAVITY OCCURRENCE IN THE MAYNARDVILLE LIMESTONE AND THE COPPER RIDGE DOLOMITE AT THE Y-12 PLANT USING LOGISTIC AND GENERAL LINEAR MODELS

L. A. Shevenell

J. J. Beauchamp

Environmental Sciences Division

Oak Ridge National Laboratory

November 1994

Prepared for the

Environmental Management Department

Health, Safety, Environment, and Accountability Organization Oak Ridge Y-12 Plant

Oak Ridge, Tennessee 38731 managed by

MARTIN MARIETTA ENERGY SYSTEMS, INC. for the

U.S. DEPARTMENT OF ENERGY under contract

DE-AC05-84OR21400 PFCENVEMAR 311995

OSTI

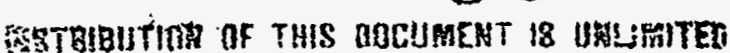
i 


\section{DISCLAIMER}

This report was prepared as an account of work sponsored by an agency of the United States Government. Neither the United States Government nor any agency thereof, nor any of their employees, makes any warranty, express or implied, or assumes any legal liability or responsibility for the accuracy, completeness, or usefulness of any information, apparatus, product, or process disclosed, or represents that its use would not infringe privately owned rights. Reference herein to any specific commercial product, process, or service by trade name, trademark, manufacturer, or otherwise, does not necessarily constitute or imply its endorsement, recommendation, or favoring by the United States Government or any agency thereof. The views and opinions of authors expressed herein do not necessarily state or reflect those of the United States Government or any agency thereof.

\section{COPYRIGHT NOTICE}

The submitted manuscript has been authored by a contractor of the U.S. Government under contract DE-AC05-84OR21400. Accordingly, the U.S. Government retains a paid-up, nonexclusive, irrevocable, worldwide license to publish or reproduce the published farm of this contribution. prepare derivative works. distribute copies to the public, and perform publicly and display publicly, or allow others to do so, for U.S. Government purposes. 


\section{DISCLAIMER}

Portions of this document may be illegible in electronic image products. Images are produced from the best available original document. 


\title{
EVALUATION OF CAVITY OCCURRENCE IN THE MAYNARDVILLE LIMESTONE AND THE COPPER RIDGE DOLOMITE AT THE Y-12 PLANT \\ USING LOGISTIC AND GENERAL LINEAR MODELS
}

Prepared by:

L. A. Shevenell(1)

John J. Beauchamp (2)

Environmental Sciences Division

Oak Ridge National Laboratory

\author{
Prepared for the \\ Environmental Management Department \\ Health, Safety, Environment, and Accountability Organization \\ Oak Ridge Y-12 Plant \\ Oak Ridge, Tennessee 37831
}
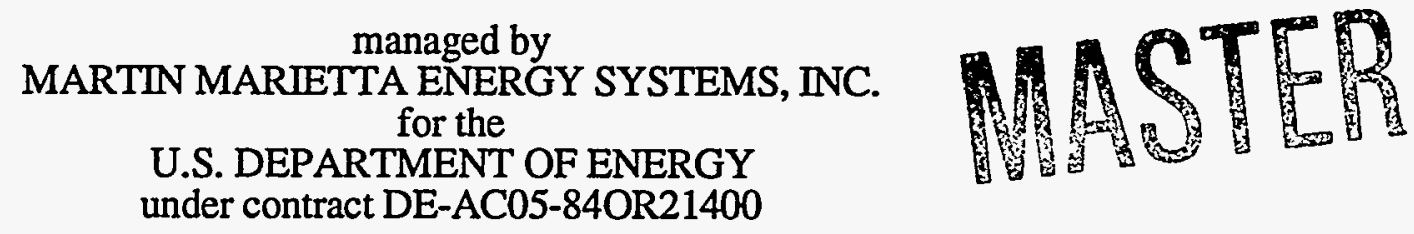

(1) Nevada Bureau of Mines and Geology, University of Nevada, Reno, NV

(2) Engineering Physics and Mathematics Division, Oak Ridge National Laboratory, Oak Ridge, TN 



\section{CONTENTS}

List of Figures . . . . . . . . . . . . . . . . . . . iv

List of Tables . . . . . . . . . . . . . . . . . . . . v

Abbreviations . . . . . . . . . . . . . . . . . . . . . . . vi

EXECUTIVE SUMMARY . . . . . . . . . . . . . . . . . . . vii

INTRODUCTION . . . . . . . . . . . . . . . . . . . . . . . . 1

BACKGROUND ..................... 1

PROCEDURE . . . . . . . . . . . . . . . . . . . 3

General Linear Model c . . . . . . . . . . . . . . . . . 6

Logistic Model . . . . . . . . . . . . . . . . . 6

RESULTS . . . . . . . . . . . . . . . . . . . . . 7

General Linear Model c . . . . . . . . . . . . . . . 7

Logistic Model . . . . . . . . . . . . . . . . . . . . . . 8

DISCUSSION . . . . . . . . . . . . . . . . . . . . . . 10

CONCLUSIONS AND RECOMMENDATIONS . . . . . . . . . . . . . . 20

ACKNOWLEDGMENTS . . . . . . . . . . . . . . . . . 21

REFERENCES . . . . . . . . . . . . . . . . . 21

Appendices . . . . . . . . . . . . . . . . . . . . . . . . . . 22

Appendix A: Listing of water zones in the $\mathrm{Cmn}$ and $\mathrm{Ccr}$ used in this report . . . . . . 24

Appendix B. Selected GLM model results for both transformed and non-transformed data. . . . . . . . . . . . . . . . . . . . . . . . 36

Appendix C. Comparison of selected model results with and without the use of the

$\mathrm{DBC}$ variable. . . . . . . . . . . . . . . . . . . . . . . . 39

Appendix D. Summary of selected logistic model results. Variables are transformed unless otherwise noted. 


\section{LIST OF FIGURES}

Figure 1. Generalized geologic map of the Oak Ridge Reservation. Modified from Hatcher, et al. (1992)

Figure 2. General locations of the Cmn Pickets at the Y-12 Plant . . . . . . . . . 15 


\section{LIST OF TABLES}

Table 1. Occurrence of cavities in wells drilled in the Cmn and Ccr as of August, 1992.

Table 2. Distribution of cavities by size in the $\mathrm{Cmn}$ and Ccr. . . . . . . . . . . . . . . . 4

Table 3. Elevations of cavities encountered in wells in the Cmn and Ccr. . . . . . . . . . . 5

Table 4. Ranges in values of variables used in models incorporating the $\mathrm{DBC}$ variable. . . . . . 9

Table 5. Summary of results of reduced data sets in the Cmn with the use of transformed variables. The files are subsets of $\mathrm{Cmn} 9$ (incomplete observations were deleted).

Table 6. Number of cavities predicted in the Cmn as a $>70 \%$ probability of occurrence at Pickets J, A, and W.

Table 7. Water zones encountered in the $\mathrm{Cmn}$ by depth in both the full an reduced data sets.

Table 8. Summary of water breaks by elevation above MSL (based on data from Cmn picket wells in Shevenell et al., 1992). . . . . . . . . . . . . . . . . . . . 15

Table 9. Summary of the frequency of water zones by well and depth in the Ccr and Cmn. . . . 18

Table 10. Occurrence of cavities in the $\mathrm{Cmn}$. $\quad . \quad$. . . . . . . . . . . . . . . . . . . 19

Appendix A. Listing of water zones in the $\mathrm{Cmn}$ and $\mathrm{Ccr}$ used in this report . . . . . . . . 24

Appendix B. Selected GLM model results for both transformed and non-transformed data.

Appendix C. Comparison of selected model results with and without the use of the DBC variable.

Appendix D. Summary of selected logistic model results. Variables are transformed unless otherwise noted. 


\section{ABBREVIATIONS}

Ccr Copper Ridge Dolomite

Cmn Maynardville Limestone

DBC Depth of water zone above or below the $\mathrm{Cmn}-\mathrm{Ccr}$ lithologic contact

Depth Depth of water zone below ground surface ( $\mathrm{ft}$ )

D1 Dummy variable used in logistic model

D2 Dummy variable used in logistic model

East East coordinate in feet (in Y-12 grid)

Elev Elevation of the water zone in feet above mean sea level

GLM General Linear Models

H Well encountering a particular water zone is located on a hill

Loc Location of the well in which the water zone is encountered (i.e., on a ridge, or hill, or in a valley)

LOG Logistic model

North North coordinate in feet (in Y-12 grid)

ORR Oak Ridge Reservation

Size Size of a cavity as determined during drilling; the length over which the drill string dropped

Type Type of water zone (used in initial GLM models) to indicate if the zone was a cavity, fracture or water zone

$\mathrm{R}$ Well encountering a particular water zone is located on a ridge

$\mathrm{V}$ Well encountering a particular water zone is located in a valley 


\section{EXECUTIVE SUMMARY}

Several waste disposal sites are located on or adjacent to the karstic Maynardville Limestone (Cmn) and the Copper Ridge Dolomite (Ccr) at the Oak Ridge Y-12 Plant. These formations receive contaminants in groundwaters from nearby disposal sites, which can be transported quite rapidly due to the karst flow system. In order to evaluate transport processes through the karst aquifer, the solutional aspects of the formations must be characterized. As one component of this characterization effort, statistical analyses were conducted on the data related to cavities in order to determine if a suitable model could be identified that is capable of predicting the probability of cavity size or distribution in locations for which drilling data are not available. Existing data on the locations (East, North coordinates), depths (and elevations), and sizes of known conduits and other water zones were used in the analyses.

Two different models were constructed in the attempt to predict the distribution of cavities in the vicinity of the Y-12 Plant: General Linear Models (GLM), and Logistic Regression Models (LOG). Each of the models attempted was very sensitive to the data set used. Models based on subsets of the full data set were found to do an inadequate job of predicting the behavior of the full data set. The fact that the Ccr and $\mathrm{Cmn}$ data sets differ significantly is not surprising considering the hydrogeology of the two formations differs. Flow in the Cmn is generally at elevations between 600 and $950 \mathrm{ft}$ and is dominantly strike parallel through submerged, partially mud-filled cavities with sizes up to $40 \mathrm{ft}$, but more typically less than $5 \mathrm{ft}$. Recognized flow in the Ccr is generally above $950 \mathrm{ft}$ elevation, with flow both parallel and perpendicular to geologic strike through conduits, which tend to be large than those on the $\mathrm{Cmn}$, and are often not fully saturated at the shallower depths.

The LOG models formulated were not successful in predicting the probability of cavity occurrence at specific locations within the Ccr and Cmn. In the LOG models, the East and North coordinates were not important variables in the Ccr data, and the East coordinate was not an important variable in the Cmn data set. Hence, with a given elevation and north value, cavity presence or absence would be predicted regardless of the east value in the $\mathrm{Cmn}$. The model is insensitive to the east coordinate, which is reasonable given that the dominant flow direction in the Cmn is along geologic strike (E-W). Both the GLM and LOG analyses suggest that cavity size and presence in the $\mathrm{Cmn}$ is a strong function of north and elevation (or depth).

The presence or absence of a cavity at a given location can not be predicted using the models attempted because not all the variables, which define a point in space are significant in the models. Numerous other controlling variables were not included in the model due to lack of data at many of the locations. For instance, the presence or absence of a cavity is likely to be function of lithology, zone thicknesses, and matrix porosity values, and such variables would give an indication of the ease of dissolution. These types of data, in addition to hydrologic data, could be examined on localized areas where sufficiently detailed data are available, but were not considered in this report because these data are not known at most well bore locations. Given the complexities of the karst flow system, it is possible that other models, which incorporate geologic data would also be inadequate in predicting cavity occurrence, because insufficient data are available at most locations. 


\section{INTRODUCTION}

Karst aquifers can have a profound effect on contaminant transport rates when waste disposal facilities are located on or adjacent to them. Several waste disposal sites are located adjacent to the karst Cambrian Maynardville Limestone ( $\mathrm{Cmn}$ ), and on the Cambrian Copper Ridge Dolomite (Ccr) at the U.S. Department of Energy Y-12 Plant on the Oak Ridge Reservation (ORR) in Oak Ridge, TN. The Cmn is the upper member of the Conasauga Group and the Ccr is the lower member of the Knox Group. The study area in this report is along Bear Creek Valley near the Y-12 Plant in the lower Knox Group (Ccr) which forms Chestnut Ridge, and the upper Conasauga Group (see Fig. 1).

The Cmn overlies the Cambrian Nolichucky Shale and was deposited in an upward shallowing subtidal to intertidal carbonate platform environment (Goldstrand, in press). The Cmn has previously been subdivided into six informal zones where the bottom is identified as zone 2 and the top is zone 6 . Zones 1 and 7 are transitional between the $\mathrm{Cmn}$ and the Nolichucky Shale, and the Cmn and the Ccr, respectively (Shevenell et al., 1992). The following lithologic descriptions are summarized from Goldstrand (in press). Zone 2 consists dominantly of thrombolitic limestone, and solution zones and vugs are common and related to dissolution along interbeds of carbonate mudstone and interfaces of shale strings. Solution features are also due to dedolomitization and localized oxidation of pyrite. Zone 3 consists of interbedded thrombolitic limestones with subtidal oncolitic, and oolitic limestones. Dissolution features are more commonly associated with the thrombolitic limestones. Zone 4 consists of coarsely crystalline peloidal and oolitic limestone, and secondary porosity is limited. However, dissolution features found in zone 4 are related to dissolution of intervening carbonate mudstones interbedded with stromatolitic and thrombolitic limestones. Zone 5 consists of laterally extensive oolitic limestone with interbeds of shale and carbonate mudstone. Dedolomitization accounts for most of the secondary micro-porosity. The cavernous intervals in this zone are associated with fractures or faults. Zone 6 consists of stromatolitic dolostone and dolomitic limestone. This unit has higher porosities than other $\mathrm{Cmn}$ zones with vugs and cavities being formed by dissolution of evaporite nodules. Dedolomitization is common throughout this zone and is responsible for much of the micro-porosity development (Goldstrand, in press).

Several ideas and concepts pertaining to the nature, extent, and the behavior of the karst aquifers at the Y-12 Plant require refinement. Results from a recent drilling project appear in Shevenell et al. (1992). The geochemical characteristics of the groundwaters as they relate to identifying quick flow water intervals through fractures and conduits have previously been evaluated (Shevenell, in press). Detailed lithologic descriptions, diagenetic interpretations, and evaluation of secondary porosity development are documented in Goldstrand (in press) and Goldstrand et al. (in prep.). The ultimate objective of the overall studies of the Cmn is to be able to predict the distribution of conduits and, therefore, flow paths for groundwater and potential contaminant transport in these rock units.

The purpose of conducting statistical analyses on the data related to cavities at the Y-12 Plant is to determine if a suitable model can be identified which is capable of predicting cavity size or the probability of cavity occurrence in locations for which drilling data are not available. If an acceptable model can be identified, then the analyses are to be used to predict the locations and/or sizes of cavities throughout the $\mathrm{Cmn}$ and $\mathrm{Ccr}$. Cavity occurrence is associated with rapid fluid velocities and Locally high hydraulic conductivities are associated with cavity occurrence and rapid fluid velocities. The distribution of cavities, if they can be predicted, can be used to conduct groundwater flow modeling and predict possible, preferential flow paths.

\section{BACKGROUND}

To effectively evaluate groundwater and surface water contamination and contaminant migration from waste sites at the Y-12 Plant, a Comprehensive Groundwater Monitoring Plan (Comprehensive Plan) was developed to guide monitoring of surface water and groundwater quality at the Y-12 Plant (Geraghty and Miller, 1990). A previous report (Shevenell et al., 1992) describes the implementation of the Maynardville Limestone exit pathways project, which is a portion of the Comprehensive Plan (Maynardville 


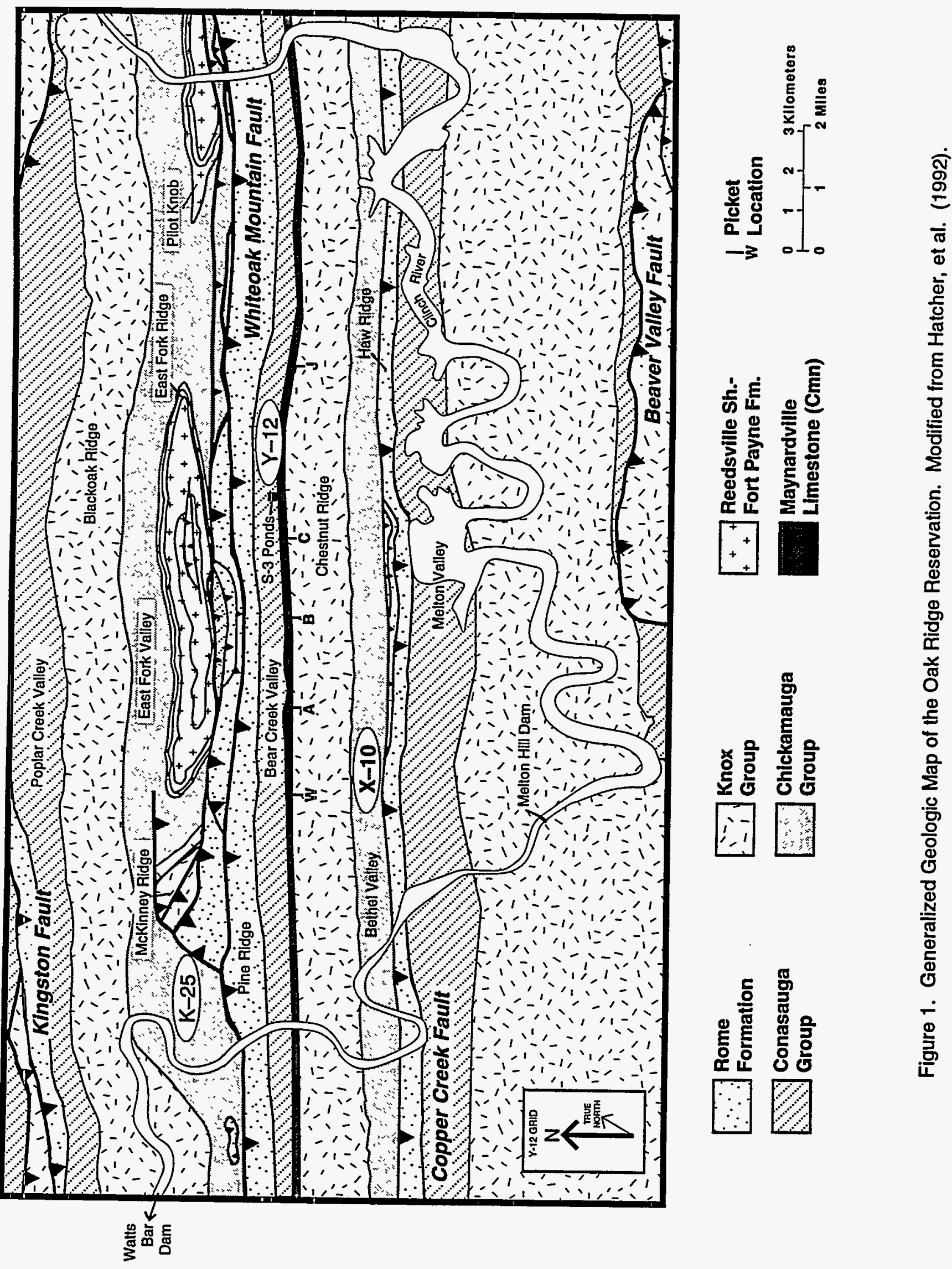


Project). The $\mathrm{Cmn}$, which underlies the axis of Bear Creek Valley (BCV), is considered to be the primary pathway for groundwater leaving the Y-12 Plant (King and Haase, 1988). Because the Cmn and the Ccr are in hydraulic continuity, the cavities in both formations are investigated in this report.

Over 800 water producing intervals have been identified in the $\mathrm{Cmn}$ and $\mathrm{Ccr}$, and additional intervals continue to be encountered as drilling proceeds. The data used in this report are from Jones et al. (1992) and Dreier et al. (1993). Of the 800 intervals noted thus far, $36 \%$ have been identified as cavities, $32 \%$ have been identified as fractures, and $32 \%$ as slow flow water producing intervals (see Appendix A for listing of the intervals). Cavities are noted when an obvious drop in the drill string occurs during drilling; fractures are noted when cuttings or core have oxidized or altered surfaces, or if significant drilling rig chatter occurs in an interval. Either of the two categories (fracture or cavity) may or may not be associated with water production, thought they often are. Water zones are defined when none of the above characteristics are observed, yet small increases in water production are observed during drilling. A large percentage (66\%) of wells which have been drilled in carbonate units ( $\mathrm{Cmn}$ and $\mathrm{Ccr}$ ) at the Y-12 Plant have encountered at least one cavity (Table 1) indicating that cavities are pervasive throughout the site.

The sizes of the cavities in the Cmn and Ccr differ somewhat in that those in the Ccr tend to be slightly larger (Table 2) with up to $23 \%$ of the encountered cavities having vertical dimensions greater than $5 \mathrm{ft}$ as determined from drilling data. Often, the shallower (less than $\approx 150 \mathrm{ft}$ ) conduits in the Ccr are at or above the water table, whereas all the conduits encountered in the $\mathrm{Cmn}$ are submerged, which is reasonable given that the Ccr occurs at higher elevations than the Cmn. Several of the larger, dominantly airfilled conduits in the Ccr have recently been explored at a nearby site on the ORR (Lemiszki and Rubin, pers. comm., 1993). Recent drilling data (Shevenell et al., 1992) shows that numerous, small ( $<5 \mathrm{ft}$ ), interconnected cavities are common locally within the Cmn. Data in Table 2 show the distribution of cavities by size. Note that the sizes of numerous cavities ( $20 \%$ in the $\mathrm{Cmn}$, and $38 \%$ in the Ccr) were not noted during drilling. In many of the older wells drilled prior to 1987 , only the depth to the top of a cavity was noted. In addition, it is believed that many of the older records are not accurate and may not have noted cavities when they were encountered. Recent plugging and abandonment activities at some of these older wells indicate that information such as total depths and screened interval depths where documented incorrectly during drilling (Jago, pers. comm., 1993).

Occurrence of cavities by elevation is listed in Table 3. It should be noted that the data are biased by the depths to which wells have been drilled. Few wells have been drilled to depths greater than $300 \mathrm{ft}$ (elevations less than 600 to $700 \mathrm{ft}$ ). The Ccr is a ridge former on the ORR, hence most (73\%) of the conduits occur at elevations $>950 \mathrm{ft}$. No cavities have yet been encountered in the Ccr at elevations less than $700 \mathrm{ft}$ (depths $\approx 400 \mathrm{ft}$ ). The Cmn subcrops in BCV (valley floor elevations $\approx 800$ to $900 \mathrm{ft}$ ), and hence, most ( $\approx 83 \%)$ cavities occur at lower elevations $(<950 \mathrm{ft})$.

\section{PROCEDURE}

The locations of cavities are likely to be related to many interacting variables. The following factors are believed to be important in cavity occurrence: (1) location relative to the Cmn subcrop, (2) the particular Cmn zone (ie. zone 6 contains abundant vugs (Goldstrand, in press)), (3) depth below ground surface, (4) location relative to major springs, sinkholes and faults and fractures, (5) location relative to Chestnut Ridge, and (6) location relative to crosscutting valleys (strike perpendicular valleys). Insuffcient data are available on the location of individual $\mathrm{Cmn}$ zones because these zones have only been identified within the past few years, and all older wells do not have this information. Hence, these data could not be incorporated into a model. Items (1) and (5) were qualitatively incorporated into the models discussed below by noting if wells were drilled on the ridge, hillside or in the valley. Data for item (4) is unknown in many cases (i.e., faults and fractures) when referring to these characteristics in relation to particular water zones encountered at depth. In the particular models discussed here, the 3-D location of known cavities (north, east, depth) was selected for use in the attempt to predict cavity locations. 
Table 1. Occurrence of cavities in wells drilled in the $\mathrm{Cmn}$ and $\mathrm{Ccr}$ as of August, 1992.

$\mathrm{Cmn}$

Total number of wells

$\%$ of wells intersecting at least one cavity

$\%$ of wells intersecting

2 or more cavities

122

$67 \%$

$42 \%$
Cor

$\mathrm{Cmn}+\mathrm{Cgr}$

70

192

$64 \%$

$66 \%$

$31 \%$

$38 \%$ 
Table 2. Distribution of cavities by size in the Cmn and Ccr. Cavity size (Cavity size is determined on the vertical drop in the drill string during drilling.)

\begin{tabular}{lcc}
\hline \multicolumn{1}{c}{ Distribution } & Cmn & Ccr \\
\hline$\%$ of Cavities with size $<1 \mathrm{ft}$ & $16 \%$ & $1 \%$ \\
$\%$ of Cavities with size 1 to $4.99 \mathrm{ft}$ & $52 \%$ & $38 \%$ \\
$\%$ of cavities with size 5 to $9.99 \mathrm{ft}$ & $6 \%$ & $11 \%$ \\
$\%$ of cavities with size $>10 \mathrm{ft}$ & $6 \%$ & $12 \%$ \\
$\%$ of cavities with unknown size & $20 \%$ & $38 \%$ \\
\hline
\end{tabular}

Table 3. Elevations of cavities encountered in wells in the $\mathrm{Cmn}$ and Ccr.

\begin{tabular}{ccc}
\hline Elevation & Cmn & Ccr \\
\hline$<600 \mathrm{ft}$ & $1 \%$ & $0 \%$ \\
600 to $699 \mathrm{ft}$ & $2 \%$ & $0 \%$ \\
700 to $799 \mathrm{ft}$ & $7 \%$ & $1 \%$ \\
800 to $899 \mathrm{ft}$ & $24 \%$ & $6 \%$ \\
900 to $949 \mathrm{ft}$ & $50 \%$ & $20 \%$ \\
950 to $999 \mathrm{ft}$ & $16 \%$ & $28 \%$ \\
$>1000 \mathrm{ft}$ & $2 \%$ & $45 \%$ \\
\hline
\end{tabular}


Two different classes of models were constructed in the attempt to predict the size (vertical dimension obtained from drilling records) and locations of cavities in the vicinity of the Y-12 Plant: general linear models (GLM), and logistic regression models (LOG). The statistical package SAS/STAT (SAS Institute Inc., 1992) was used to compare possible controlling variables in both models.

\section{General Linear Model}

A predictive model was sought relating the measured cavity size to its location (surveyed East and North coordinates of the well bores), depth below ground surface (Depth) or elevation above mean sea level (Elev.), and location ( $L O c$ ) of the well intersecting the cavity (i.e., on a ridge, hill, or valley). The north and east coordinates were not normalized relative to geologic strike because because the Y-12 eastwest coordinate is approximately parallel to strike.

GLM modeling procedures were first attempted. GLM uses use linear least squares methods to fit a selected model that describes the relationship between one dependent variable (Size), and one or more explanatory or predictor variable(s). The GLM procedure allows for the explanatory variables to be both continuous numeric variables and class variables which have one or more discrete levels. In the case of the models described here, a class variable was used to describe location of monitoring wells. Wells are located on either ridge tops $(R)$, sloping portions of hills $(H)$, or valleys $(V)$; hence the class variable location (LOC) has three levels. The complete model includes first and second order (polynomial effects) terms, as well as crossed effects for the continuous variables East, North, Elev, and Type (type of water interval which is either a cavity, fracture or slow-flow water interval). Crossed effects refer to terms composed of two variable multiplied by one another and by a coefficient (eg. Coefficient $\times$ Elev $\times$ East). In addition, main effects for the class variable (Loc), as well as interactions of this variable with the continuous variables are included in the model. The presence of the interaction terms allows for differences in the effect of the continuous explanatory variables on the dependent variable at the different locations.

Non-cavities (slowly flowing water intervals, or fractures) were assigned "0" size and the actual size of the cavity noted during drilling was used for the cavities. Different models were constructed using either the raw data (East and North in $\mathrm{ft}$, Elev in $\mathrm{ft}$ above mean sea level (amsl), Size in $\mathrm{ft}$ ), or transformed data (East and North in $\mathrm{km}, \log ($ Elev $), \log ($ Size +1$)$ ).

\section{Logistic Model}

The LOG model procedure used in this work employs the method of maximum likelihood to fit linear logistic regression models to binary response data. The logistic regression analysis is used to evaluate the relationship between the probability of cavity occurrence and the explanatory variables used in this work (ie. East, North, etc.). The response variable (probability of cavity presence, p) is assumed to be related to the explanatory variables through the logit function given by

$$
\operatorname{logit}(\mathrm{p})=\ln \left(\frac{\mathrm{P}}{1+\mathrm{P}}\right)=\beta_{0}+\beta_{1} \mathrm{x}_{1}+\ldots+\beta_{\mathrm{p}} \mathrm{x}_{\mathrm{p}}
$$

where $x_{1}, \ldots, x_{p}$ represent the linear and quadratic terms for the continuous explanatory variables as well as the main effects and interactions of the class variable with the continuous variables. The $\beta$ 's are coefficients to be estimated from the observed data. The size variable was no longer included in the model. A " 1 " was assigned to slow flowing water intervals (non-cavities) and a "0" was assigned to cavities in an effort to predict the probability of the presence of cavities in specific locations.

Logistic models were run for both the $\mathrm{Ccr}$ and $\mathrm{Cmn}$ data sets using an extended model as described in equation (1). After formulating several LOG models using the same data set as was utilized in the GLM modeling, an additional attempt to use a LOG model to estimate the probability of conduit presence in specific locations was made by deleting all data from wells drilled prior to 1987 (well numbers less than GW-500). During recent plugging and abandonment activities at the Y-12 Plant, the available data from several of the older wells has been found to be faulty. The locations and total depths of wells were 
apparently reported incorrectly following well completion at a mumber of sites (W.K. Jago, pers. comm, 5/93). Hence, the reliability of recorded well completion information from wells drilled prior to 1987 is questionable. The reduced data set formed by deleting pre-1987 well data in the $\mathrm{Cmn}$ includes 185 water intervals, in 45 separate wells, of which 45 are cavities.

\section{RESULTS}

\section{General Linear Model}

Several models were constructed using both the raw data (East and North in feet, Elev in feet above mean sea level, Size in feet) and transformed data (East and North in $\mathrm{km}, \log (E l e v), \log ($ Size +1$)$ ). Only selected models are discussed here, and Appendices B and $C$ list summary results from these selected models. An " $\mathrm{X}$ " in a column in Appendix B indicates that the particular variable was utilized in the given model. Columns with an "*" between two variables (ie. East*Loc) indicate that the cross product between the two variables (East and $L O c$ ) was incorporated into the model.

Results from Cmn, Ccr and both data sets were compared between models that used Depth and those which used Elev instead of the Depth variable. $R^{2}$ values were similar when either Depth or Elev was used. The use of either Depth or Elev for the $Z$ coordinate had negligible effect on the calculated $R^{2}$ values, which is not surprising given that the two are linearly related.

In some cases, slightly better squared multiple correlation coefficient $\left(R^{2}\right)$ values were obtained with the transformed variables. However, other models have poorer $\mathrm{R}^{2}$ values using the transformed data (compare file Ccr-2 to Ccr-6, Appendix B) indicating that these simple transformations can not be used to improve results appreciably. Since the $\mathrm{R}^{2}$ values for $\mathrm{Ccr}-2$ and $\mathrm{Ccr}-6$ are calculated in different spaces (i.e., transformed versus untransformed), the differences in $\mathrm{R}^{2}$ values may not be significant.

Much poorer results were obtained with the Cmn data set where $\mathrm{R}^{2}$ values are all less than 0.40 (Appendix B). Models using all wells in the Ccr and Cmn together also had poor $\mathrm{R}^{2}$ values, similar to models run using only the $\mathrm{Cmn}$ water intervals. The $\mathrm{Cmn}$ results were consistently worse than analyses using only the Ccr intervals (Appendices B and C). The fact that the Ccr and Cmn data sets have distinctly different $\mathrm{R}^{2}$ values is not surprising considering the hydrogeology of the two differs. Flow in the $\mathrm{Cmn}$ is generally at elevations between 600 and $950 \mathrm{ft}$ and is dominantly strike parallel through submerged, partially mud filled cavities with sizes up to $40 \mathrm{ft}$ in vertical dimensions, but more typically less than $5 \mathrm{ft}$. The flow in the Ccr is generally above an elevation of $950 \mathrm{ft}$ with flow both parallel and perpendicular to geologic strike through conduits which tend to be larger, and are often not fully saturated at the shallower depths.

Most analyses were, hence, conducted separately on the Cmn intervals and the Ccr intervals, and poor correlations were seen in all cases (Appendices B and C). In an attempt to improve predictions, another variable was introduced: the top of the water interval depth below the Ccr/Cmn contact (DBC). However, this data set was much smaller because the $\mathrm{Cmn} / \mathrm{Ccr}$ contact is only encountered in a small number of wells. The Ccr data set decreased from 290 to $39\left(R^{2}\right.$ increased from about 0.4 to 0.83 ), and the Cmn data set decreased from 390 to $133\left(\mathrm{R}^{2}\right.$ increased from about 0.31 to 0.33$)$.

To determine if these smaller data sets were representative, the same models were run by simply removing the $\mathrm{DBC}$ variable to identify if this variable is important. Removing $\mathrm{DBC}$ from these new, smaller data files had no effect on the $\mathrm{R}^{2}$ suggesting that the introduction of a new variable was not responsible for the better predictive capability of the model (see Appendix C; compare Cmn-5 with Cmn-5a, and Ccr-14 with Ccr-15). When an identical model is run using the larger data set (ie. compare Ccr-16 with Ccr-15 Appendix C), the $R^{2}$ value is much worse with the larger data set $\left(R^{2}=0.11\right.$ for the 289 observation data set). The smaller subsets are apparently not representative subsets of the larger data sets and can not be used to make general statements about the larger data sets. For example, the Ccr range in the North variable is about $3400 \mathrm{ft}$ smaller in the subset than in the larger data file. In the case of the 
smaller Cmn data set, the Elev variable covered a smaller range ( $315 \mathrm{ft}$ less), and the North and East variables had a smaller range by $\approx 1200$ and $32,000 \mathrm{ft}$, respectively, than did the complete data set (see Table 4). The best $R^{2}$ values were obtained from the subset which is not representative of the data set as a whole. The predictive capabilities of the GLM models were, hence, not suitable for the data set being modeled.

In the 39 observation Ccr subset, East, Loc and East*Loc were usually the dominant variables (smallest $P$ values in Appendix C, file Ccr-14), whereas North was of importance in the larger data set (Ccr-16). Elev and East*Loc were the dominant variables in the 133 observation subset of Cmn (Cmn-13, Appendix C). Elev, Elev*Elev, $\mathrm{N}^{*} \mathrm{Elev}$, and North*North were dominant in the complete data set (cmnall, Appendix C). Note that in the Cmn-5a model (Appendix C), Loc, East, North, Elev and East*Loc were the only variables used in the 133 observation data set, and all were important; however, the model resulted in a low $\mathrm{R}^{2}$ value of 0.308 . Note that the crossed effect North*Elev was not found to be significant in the models. This crossed effect could provide an indirect indication of the influence of the lithology in particular Cmn zones, because individual Cmn zones occur nearly continuously along constant North values in the east-west direction, and at the same elevation in an east-west direction. Hence, the particular variables, and their crossed effects, in these models can not explain all of the variability in the data set. No other variables are available for inclusion into the model because none have been measured in relation to water intervals in a sufficient number of the wells.

\section{Logistic Model}

Following failure to identify general linear models capable of explaining a large percentage of the variability in the observed cavity size in the data sets, an alternative approach using logistic regression models was investigated. A " 0 " was assigned to cavities and a " 1 " was assigned to water intervals (noncavities). Initially, an expanded model incorporating all terms and cross products was constructed. Appendix D lists selected model results along with P-values, parameter estimates (Param), and standard errors (Std. Err.) for the terms included in each model. The \% Correct column lists the percentage of known cavities which were predicted correctly in the models and sample size lists the number of water intervals (observations) included in the models.

An influence option was used in the SAS Logistic procedure (SAS, 1990) to flag influential, individual observations based on the diagnostics developed by Pregibon (1981). For instance, in the $\mathrm{cmn} 9$ file, eight water intervals were identified as influential: BC-49 (805.2 ft), GW-214 (518.78, 612.78, $594.78 \mathrm{ft}), \mathrm{GW}-646(934.01 \mathrm{ft}), \mathrm{GW}-712$ (426.11), GW-713 (714.83), and GW-727 (792.96 ft), where elevations of the water intervals are noted in parentheses. It is not clear why these individual observations are more influential than others in the data set.

A model similar to that in $\mathrm{cmn} 9$ was run (cmn10) using the stepwise selection option with a value of 0.15 being used to specify the significance level for entry into, and exclusion from, the model. The percent correctly predicted by the model was $69.8 \%$ (Appendix $\mathrm{D}$ ) and only the following variables were found to be significant in the model: location, $\mathrm{N}, \mathrm{N} \times \mathrm{N}$ (North*North), and Elv x Elv (Elev*Elev). The same variables were found to be significant using significance levels for entry and exclusion from the model of up to 0.5 , suggesting all other variables do not contribute appreciably to the explanation of the variability in the data set. Hence, the probability of cavity presence is not a strong function of the east coordinate location for this data set. Similar probabilities of cavity occurrence in the Cmn would be expected to be predicted regardless of the east location of the coordinate.

LOG models were also run on the Ccr data set using the stepwise variable selection option. The following variables were found to be the most important in the model: Elev, D2 x Elev (which is a location variable times the water interval elevation). This result was obtained for entry significance levels of 0.05 to 0.5 , suggesting all other variables do not contribute significantly to the explanation of the variability in the data set. 
Table 4. Ranges in values of variables used in the model runs incorporating the DBC variable.

\begin{tabular}{|c|c|c|c|c|c|c|c|c|}
\hline & $\underset{(289}{C}$ & $\begin{array}{l}\text { y-all } \\
\text { values) }\end{array}$ & $\begin{array}{l}\text { Ccr-s } \\
\text { (39 ve }\end{array}$ & $\begin{array}{l}\text { nall } \\
\text { lues) }\end{array}$ & $\begin{array}{l}\text { Cmn } \\
\text { (390 ve }\end{array}$ & $\begin{array}{l}\text {-all } \\
\text { lues) }\end{array}$ & $\begin{array}{l}\mathrm{Cmn} \\
(133\end{array}$ & $\begin{array}{l}\text { small } \\
\text { alues) }\end{array}$ \\
\hline & Minimum & Maximum & Minimum & Maximum & Minimum & Maximum & Minimum & Maximum \\
\hline Elevation ( $\mathrm{ft}$ ) & 428 & 1,098 & 428 & 959 & 0 & 1,017 & 252 & 954 \\
\hline Depth (ft) & 5 & 479.7 & 13 & 479.7 & 4 & 650 & 5 & 650 \\
\hline North (ft) & 24,225 & 29,027 & 27,654 & 29,027 & 27,644 & 30,393 & 27,873 & 29,405 \\
\hline East (ft) & 36,434 & 65,057 & 36,434 & 65,057 & 9088 & 69,712 & 36,434 & 65,057 \\
\hline $\begin{array}{l}\text { Ranges: } \\
\text { Elevation (ft) }\end{array}$ & & 670 & & 531 & & 1017.2 & & 702 \\
\hline Depth (ft) & & 474.7 & & 466.7 & & 646 & & 645 \\
\hline North (ft) & & 4,802 & & 1,373 & & 2,749 & & 1,532 \\
\hline East (ft) & & 28,623 & & 28,623 & & 60,624 & & 28,623 \\
\hline $\begin{array}{l}\text { Differences: } \\
\text { Elevation (ft) }\end{array}$ & & & 139 & $79 \%$ & & & 315.2 & $69 \%$ \\
\hline Depth (ft) & & & 8 & $98 \%$ & & & 1 & $100 \%$ \\
\hline North (ft) & & & 3,429 & $29 \%$ & & & 1,217 & $56 \%$ \\
\hline East (ft) & & & 0 & $100 \%$ & & & 32,001 & $47 \%$ \\
\hline
\end{tabular}


The influence option was utilized in several models and several water intervals (observations) were flagged as being influential in the results. Even though there was no physical reason to suspect the data from these intervals were in error, all were deleted from their respective files, and the models re-run. Negligible differences in results were observed following deletion of these intervals (ie. compare ccr la-all with ccr3a-all, and cmn3a-all with cmn6a-all in Appendix D).

The N-S range of values for the Cmn is $2749 \mathrm{ft}$, whereas the E-W extent of the data covers a length of $60,624 \mathrm{ft}$ (Table 4). Because the 3-D data set is long and narrow, the estimated logistic function may not be numerically stable. Because the N-S dimensions of the $\mathrm{Cmn}$ study area are much less than the EW dimensions, the study area was split into six segments in which the E-W dimensions were reduced to only two times the N-S dimensions. Models containing the same variables as $\mathrm{cmn} 9$ were run using the stepwise select option with entry significance levels of 0.15 (see Table 5 for results). Although variables involving Elev are important in four of the six subsets, it is clear that different variables are important in different portions of Bear Creek Valley.

As noted in the Procedures section, the final analysis involved deleting all data from wells drilled prior to 1987. Depth, rather than Elev, was used as a variable. Initial attempts to normalize the data by subtracting the mean from the variable value and dividing by the standard deviation did not yield appreciably improved model results. Hence, all variable values were divided by the mean value of that variable in order to normalize the data, and results improved. The percent of known cavities whose locations were predicted correctly is $81.1 \%$, with a $36.1 \%$ and $14.8 \%$ false positive and false negative rate, respectively (cmn2a, Appendix D). Of the 45 known cavities in the data set, only 15 were predicted to have a $270 \%$ probably of occurrence. Nevertheless, the model was used in an attempt to predict the locations of cavities in the $\mathrm{Cmn}$ and evaluate how the model would behave in different portions of the aquifer.

The best LOG model was identified (cmn2a, Appendix D), and gridded data sets were constructed in order to be inserted into the model and used to predict the probability of cavity occurrence at specific locations. A $10-\mathrm{ft}$ grid was utilized for both the Depth and North parameters, whereas a 100-ft grid was used for the East coordinate because previous analyses indicated the model was relatively insensitive to this variable. Only those locations in which a $>70 \%$ probability of cavity occurrence were predicted were directed to an output file. This $70 \%$ limit was somewhat arbitrarily selected.

The model was used to predict the probability of cavity occurrence from gridded data sets in the vicinity of Picket W (E-W grid extent $=2500 \mathrm{ft}$ ), Picket $\mathrm{A}(\mathrm{E}-\mathrm{W}$ grid extent $=3200 \mathrm{ft})$, and Picket $\mathrm{J}(\mathrm{E}-\mathrm{W}$ grid extent $=2800 \mathrm{ft}$; see Figs. 1 and 2 for locations of pickets). Table 6 summarizes the results and shows that 10.5 to $15.4 \%$ of gridded points in Picket $\mathrm{J}$ were predicted to be locations of cavities when screened for probabilities of $270 \%$. No cavities were predicted at Picket A, whereas cavities were predicted in about $6 \%$ of all gridded points at Picket W. Given that more cavities occur the Cmn in the Picket $J$ vicinity than in the Picket $W$ area, the results seem to reasonably reflect the field data. However, no cavities were predicted at Picket A, yet five cavities in two wells were encountered during drilling at the Picket A site (Jones et al., 1992). In addition, there is known hydraulic communication between conduits in one well (GW-684) and a local spring (Shevenell, et al., 1992) suggesting that this is an area of active conduit flow. A serious gap in prediction of cavity occurrence is located along a $3200 \mathrm{ft}$ distance near Picket $A$, and this is completely unrealistic given that cavities are know to occur in this area.

\section{DISCUSSION}

Although the best identified LOG model does not reliably predict the probability of cavities being located in particular positions, it is successful in predicting the general configuration of cavity occurrence. Examination of results of the models at Pickets $J$ and $W$, reveals that a cavity is very frequently predicted to occur at the shallowest grid points. No cavities were predicted at depths greater than $85 \mathrm{ft}$. Often, when a cavity was predicted at one shallow (e.g. $5 \mathrm{ft}$.) grid in a particular East and North location, cavities would also be predicted at the subsequent vertical grid points (i.e., at $5,15,25,35$, and $45 \mathrm{ft}$ ). The model predicts a high probability of cavity occurrence at shallow ( $<100 \mathrm{ft}$ ) depths, and this is recognized based 
Table 5. Summary of results of reduced data sets in the $\mathrm{Cmn}$ with the use of transformed variables. The files are subsets of Cmn9 (incomplete observations were deleted).

\begin{tabular}{ccccc}
\hline File & $\begin{array}{c}\text { East Range } \\
\text { (ft) }\end{array}$ & $\begin{array}{c}\text { Important } \\
\text { Variables* }\end{array}$ & Correct & $\begin{array}{c}\text { Number of } \\
\text { Observations }\end{array}$ \\
\hline e-spli1 & 36,000 to 41,687 & ElevxElev & $69.20 \%$ & 52 \\
e-spli2 & 41,688 to 47,237 & ExElev & $79.10 \%$ & 43 \\
e-spli3 & 47,238 to 52,856 & ExN, ExDum1, NxElev & $80.40 \%$ & 107 \\
e-spli4 & 52,857 to 58,475 & ExN & $75.00 \%$ & 72 \\
e-spli5 & 58,476 to 64,093 & +4 & $53.80 \%$ & 39 \\
e-spli6 & 64,094 to 69,712 & ElevxElev & $85.40 \%$ & 41 \\
& & & Ave $=73.8 \%$ & \\
\hline
\end{tabular}

- All subsets included the Intercept.

+ Modeling terminated following estimation of the Intercept. 
Table 6. Number of cavities predicted in the $\mathrm{Cmn}$ at a $>70 \%$ probability of occurrence at Pickets $\mathrm{J}$, $A$, and $W$.

\begin{tabular}{|c|c|c|c|c|c|c|c|}
\hline $\begin{array}{l}\text { East } \\
\text { Coordinate }\end{array}$ & $\begin{array}{l}\text { \# of Cav. } \\
\text { Predicted }\end{array}$ & $\begin{array}{l}\text { Total \# of } \\
\text { Grid Points }\end{array}$ & $\begin{array}{l}\% \text { of total } \\
>70 \% \text { Prob }\end{array}$ & $\begin{array}{l}\text { \# of } \\
\text { Wells }\end{array}$ & $\begin{array}{c}\text { \# of } \\
\text { Water } \\
\text { Zones } \\
\end{array}$ & $\begin{array}{c}\% \text { of } \\
\text { Zones = } \\
\text { Cavities }\end{array}$ & $\begin{array}{l}\text { Water } \\
\text { Zones } \\
\text { per Well }\end{array}$ \\
\hline \multicolumn{8}{|l|}{ Picket J } \\
\hline $63000-63100$ & 215 & 2,052 & $10.5 \%$ & 5 & 33 & $48.5 \%$ & 6.6 \\
\hline $63200-63500$ & 457 & 4,108 & $11.1 \%$ & & & & \\
\hline $63600-63900$ & 492 & 4,108 & $12.0 \%$ & & & & \\
\hline $64000-64300$ & 519 & 4,108 & $12.6 \%$ & & & & \\
\hline $64400-64700$ & 559 & 4,108 & $13.6 \%$ & & & & \\
\hline $\begin{array}{l}64800-65100 \\
65500-65800\end{array}$ & $\begin{array}{l}591 \\
633 \\
\end{array}$ & $\begin{array}{l}4,108 \\
4,108 \\
\end{array}$ & $\begin{array}{l}14.4 \% \\
15.4 \% \\
\end{array}$ & & & & \\
\hline Total & 3,466 & 26,700 & $13.0 \%$ & & & & \\
\hline \multicolumn{8}{|l|}{ Picket A } \\
\hline $39000-39100$ & 0 & 3,508 & $0.0 \%$ & 3 & 7 & $42.9 \%$ & 2.3 \\
\hline $41100-41200$ & 0 & 3,508 & $0.0 \%$ & & & & \\
\hline $41300-41400$ & 0 & 3,508 & $0.0 \%$ & & & & \\
\hline $41500-41600$ & 0 & 3,508 & $0.0 \%$ & & & & \\
\hline $41700-41800$ & 0 & 3,508 & $0.0 \%$ & & & & \\
\hline $\begin{array}{l}41900-42000 \\
42100-42200\end{array}$ & $\begin{array}{l}0 \\
0\end{array}$ & $\begin{array}{l}3,508 \\
3,508\end{array}$ & $\begin{array}{l}0.0 \% \\
0.0 \%\end{array}$ & & & & \\
\hline Total & 0 & 24,556 & $0.0 \%$ & & & & \\
\hline \multicolumn{8}{|l|}{ Picket W } \\
\hline $36300-36400$ & 275 & 4,447 & $6.2 \%$ & 5 & 28 & $21.4 \%$ & 5.6 \\
\hline $36500-36600$ & 276 & 4,447 & $6.2 \%$ & & & & \\
\hline $36700-36800$ & 276 & 4,447 & $6.2 \%$ & & & & \\
\hline $36900-37000$ & 275 & 4,447 & $6.2 \%$ & & & & \\
\hline $37100-37200$ & 277 & 4,447 & $6.2 \%$ & & & & \\
\hline $37300-37400$ & 282 & 4,447 & $6.3 \%$ & & & & \\
\hline $37500-37600$ & 281 & 4,447 & $6.3 \%$ & & & & \\
\hline $37700-37800$ & 282 & 4,447 & $6.3 \%$ & & & & \\
\hline $37900-38000$ & 282 & 4,447 & $6.3 \%$ & & & & \\
\hline $38100-38200$ & 285 & 4,447 & $6.4 \%$ & & & & \\
\hline $38300-38400$ & 288 & 4,447 & $6.5 \%$ & & & & \\
\hline $\begin{array}{l}38500-38600 \\
38700-38800\end{array}$ & $\begin{array}{l}288 \\
290\end{array}$ & $\begin{array}{l}4,447 \\
4,447\end{array}$ & $\begin{array}{l}6.5 \% \\
6.5 \%\end{array}$ & & & & \\
\hline Total & 3,657 & 57,811 & $6.3 \%$ & & & & \\
\hline
\end{tabular}




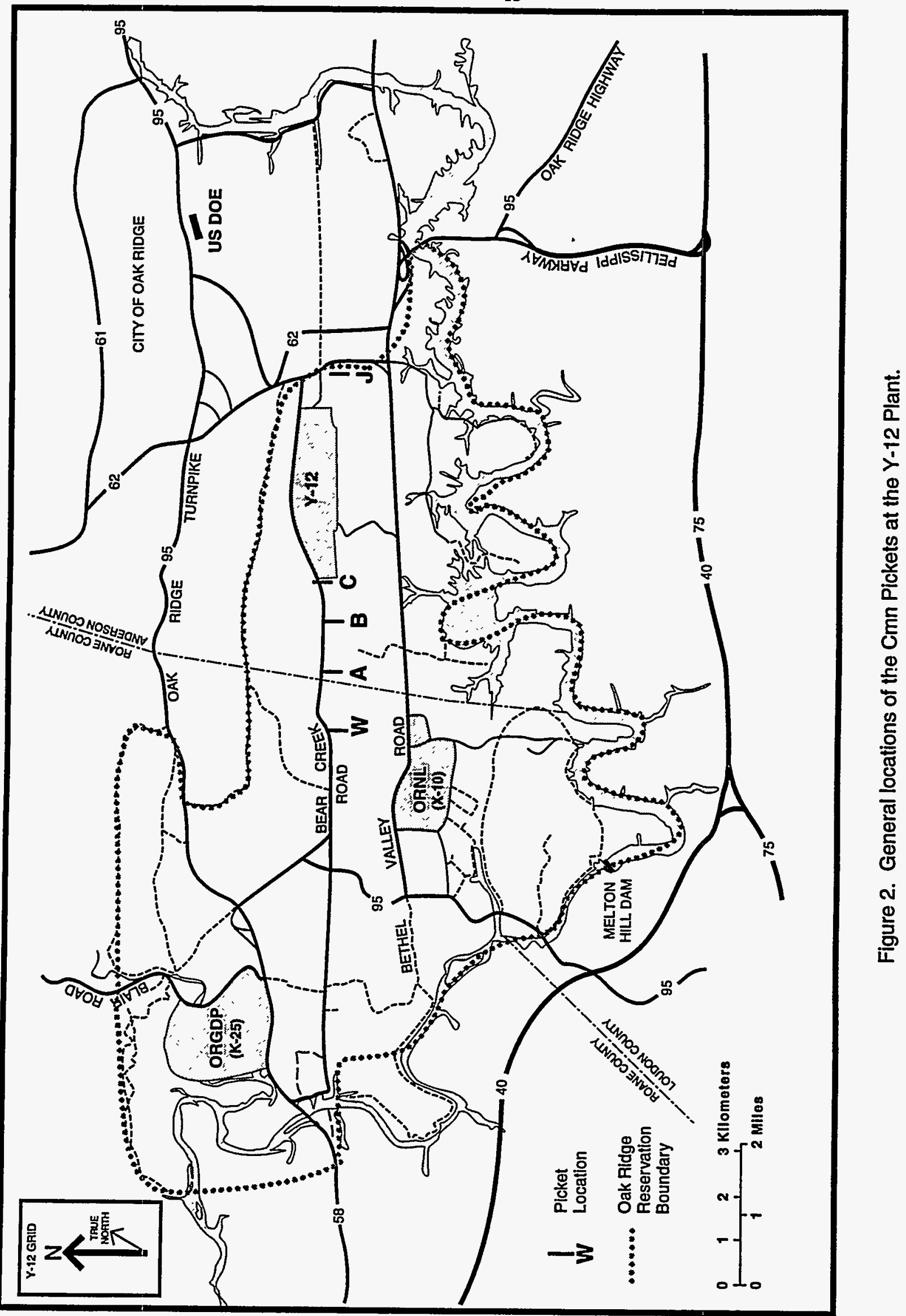


on drilling data.

Table 7 shows the total number of water intervals (observations) encountered in each of several depth intervals in the Car and Cmn for both the full data set, and reduced data set (wells newer than GW-500 are identified by 'Wells $>$ GW-500'). Note that fractures were identified during drilling by increases in water production accompanied by rig chatter, or by visible alteration on the cuttings surfaces. Using the information in this table, the data show that for the reduced Cmn data set, $45.5 \%$ of all water intervals encountered at depths $<100 \mathrm{ft}$ have been cavities, whereas only $10.5 \%$ of the water intervals have been cavities at depths $>100 \mathrm{ft}$. The percentage of cavities at shallow depths is even larger for the full data set with $55.8 \%$ of water intervals being cavities at depths $<100 \mathrm{ft}$, and $12.9 \%$ being cavities at depths $>100 \mathrm{ft}$. The data are biased in this manner because most wells are drilled to depths $<100 \mathrm{ft}$. However, it is believed that cavities are more likely to occur at shallower depths. For instance, if a small data set is taken from Shevenell et al. (1992) and evaluated based on elevation (where higher elevations correspond to shallower depths, and vice versa) one sees a distinct lack of cavities below $600 \mathrm{ft}$ elevation (Table 8). Between elevations of $\approx 0$ and $700 \mathrm{ft}$, fracture frequency tends to increase with increasing elevation from $5.3 \%$ of all water intervals to $20 \%$ of all water intervals, likely due to decreasing load on the fractures and a greater tendency for them to be open at shallower depths. At elevations greater than $700 \mathrm{ft}$, fracture frequency decreases while cavity frequencies increase from, 3.3 to $10 \%$ of all water intervals. This suggests that fractures are more likely to be enlarged through dissolution at higher elevations, and hence, shallower depths. The LOG model described was successful at duplicating this feature of the karst aquifer system.

The LOG model was also successful at representing conduits in the east-west direction. The model was insensitive to the East coordinate location which indicates this variable is not important in predicting the occurrence of cavities in the Cmn. Given that groundwater flow in the $\mathrm{Cmn}$ predominantly occurs along strike through presumably interconnected conduits and fractures, the LOG model reflects reality as it will predict cavity occurrence at a particular depth and north location with little dependence on the East location in the valley.

Each of the models attempted were very sensitive to the data set used. Subsets of the full data set could not be used to predict the behavior of the larger data set and the Cmn and Ccr data sets differ significantly. There are two obvious reasons why this would be the case: (1) the larger and smaller data sets do not exhibit the same percentage of cavities per well per depth range (Table 9), and (2) hydrologic characteristics are not homogeneous throughout the formations, as is known to be the case in the Cmn (Table 9; and see Shevenell et al., 1992). Regarding the first reason, Table 9 lists the number of cavities, fractures and water intervals per well by depth. The data in Table 9 show that the distribution of the water intervals differs between the larger and reduced data set. For instance, in the Ccr data, 0.79 fractures per well are noted for wells drilled to depths $>250 \mathrm{ft}$ in the full data set, whereas only 0.29 fractures per well are noted in the reduced data set. Similarly, in the Cmn data, the number of cavities per well in the larger data set in depth intervals of 0 to $25 \mathrm{ft}, 25$ to $50 \mathrm{ft}$, and 50 to $75 \mathrm{ft}$ is $0.40,0.52$ and 0.28 , respectively. The corresponding numbers in the reduced $(>\mathrm{GW}-500$ ) data set are $0.07,0.40$ and 0.53 , respectively. One would not expect a similar model result to be obtained from both data sets. Also see Table 4 which lists the different ranges of values for each of the two data sets.

Listings in Table 9 also illustrate that hydrologic characteristics (ie. presence of cavities) are not consistent as a function of depth, nor between the Cmn and Ccr. More cavities occur at shallow depths ( $<75 \mathrm{ft}$ ) and more fractures occur at deeper levels (>100 ft) in the Cmn, and similarly, the Cmn tends to have more cavities per well at shallow $(<75 \mathrm{ft}$ ) depths than does the Ccr. The fact that cavities tend to occur at the shallower depths is reasonable given that waters flowing to the deeper levels will likely have become saturated with respect to calcite, thus dissolution is much less likely at deeper levels (i.e., further along the flow path).

More detailed data are available from the $\mathrm{Cmn}$ than the $\mathrm{Ccr}$, and these data also show distinct variability in cavity occurrence as a function of the lithologic zone within the Cmn (Table 10). Four of the five zones contain a large percentage of the cavities, whereas no cavities have been noted in zone 3 . Note 
Table 7. Waters zones encountered in the $\mathrm{Ccr}$ and $\mathrm{Cmn}$ by depth in both the full and reduced data sets.

\begin{tabular}{|c|c|c|c|c|c|c|c|c|}
\hline \multirow[b]{2}{*}{$\begin{array}{l}\text { Water Depth } \\
\text { Ccr - All Wells }\end{array}$} & \multicolumn{3}{|c|}{ Number of Water Zones Encountered } & \multirow{2}{*}{$\begin{array}{c}\text { Total \# } \\
\text { Water Zones }\end{array}$} & \multirow{2}{*}{$\begin{array}{l}\% \text { Water } \\
\text { by Depth }\end{array}$} & \multicolumn{3}{|c|}{ Percent of Total Water Zones by Depth } \\
\hline & Cavity & Fracture & Water & & & Cavity & Fracture & Water \\
\hline 0 to $25 \mathrm{ft}$ & 7 & 9 & 4 & 20 & $6.7 \%$ & $35.0 \%$ & $45.0 \%$ & $20.0 \%$ \\
\hline 25 to 50 & 17 & 4 & 1 & 22 & $7.4 \%$ & $77.3 \%$ & $18.2 \%$ & $4.5 \%$ \\
\hline 50 to 75 & 26 & 11 & 10 & 47 & $15.7 \%$ & $55.3 \%$ & $23.4 \%$ & $21.3 \%$ \\
\hline 75 to 100 & 29 & 18 & 7 & 54 & $18.1 \%$ & $53.7 \%$ & $33.3 \%$ & $13.0 \%$ \\
\hline 100 to 125 & 22 & 21 & 16 & 59 & $19.7 \%$ & $37.3 \%$ & $35.6 \%$ & $27.1 \%$ \\
\hline 125 to 150 & 12 & 19 & 2 & 33 & $11.0 \%$ & $36.4 \%$ & $57.6 \%$ & $6.1 \%$ \\
\hline 150 to 200 & 7 & 18 & 10 & 35 & $11.7 \%$ & $20.0 \%$ & $51.4 \%$ & $28.6 \%$ \\
\hline 200 to 250 & 3 & 5 & 1 & 9 & $3.0 \%$ & 33.3\% & $55.6 \%$ & $11.1 \%$ \\
\hline 250 to ... & 1 & 11 & 8 & 20 & $6.7 \%$ & $5.0 \%$ & $55.0 \%$ & $40.0 \%$ \\
\hline Total & & & & 299 & & $41.5 \%$ & $38.8 \%$ & $19.7 \%$ \\
\hline
\end{tabular}

Max Depth Cavity: $314 \mathrm{ft}$

Max Depth Fracture: $362 \mathrm{ft}$

Max Depth Water: 479.4

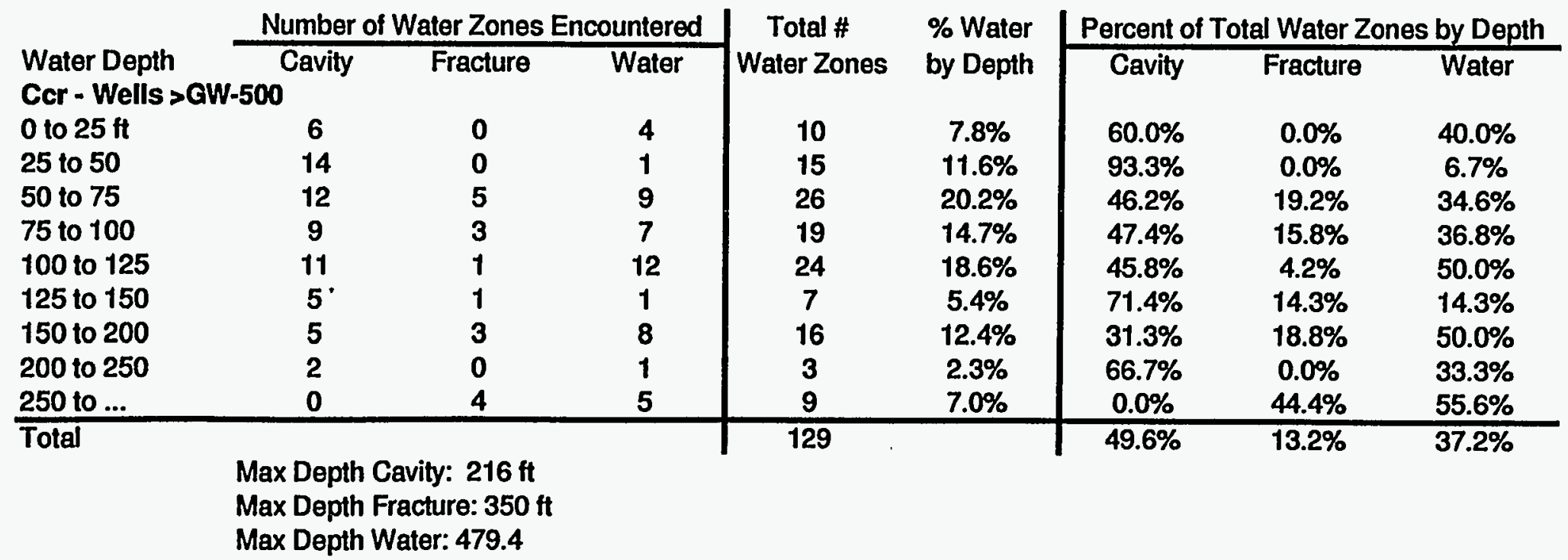


Table 7 (Continued)

\begin{tabular}{|c|c|c|c|c|c|c|c|c|}
\hline \multirow[b]{2}{*}{$\begin{array}{l}\text { Water Depth } \\
\text { Cmn - All Wells }\end{array}$} & \multicolumn{3}{|c|}{ Number of Water Zones Encountered } & \multirow{2}{*}{$\begin{array}{c}\text { Total \# } \\
\text { Water Zones }\end{array}$} & \multirow{2}{*}{$\begin{array}{l}\% \text { Water } \\
\text { by Depth }\end{array}$} & \multicolumn{3}{|c|}{ Percent of Total Water Zones by Depth } \\
\hline & Cavity & Fracture & Water & & & Cavity & Fracture & Water \\
\hline 0 to $25 \mathrm{ft}$ & 51 & 9 & 18 & 78 & $20.4 \%$ & $65.4 \%$ & $11.5 \%$ & $23.1 \%$ \\
\hline 25 to 50 & 62 & 22 & 19 & 103 & $26.9 \%$ & $60.2 \%$ & $21.4 \%$ & $18.4 \%$ \\
\hline 50 to 75 & 22 & 13 & 13 & 48 & $12.5 \%$ & $45.8 \%$ & $27.1 \%$ & $27.1 \%$ \\
\hline 75 to 100 & 5 & 9 & 8 & 22 & $5.7 \%$ & $22.7 \%$ & $40.9 \%$ & $36.4 \%$ \\
\hline 100 to 125 & 5 & 13 & 9 & 27 & $7.0 \%$ & $18.5 \%$ & $48.1 \%$ & $33.3 \%$ \\
\hline 125 to 150 & 1 & 10 & 11 & 22 & $5.7 \%$ & $4.5 \%$ & $45.5 \%$ & $50.0 \%$ \\
\hline 150 to 200 & 2 & 15 & 16 & 33 & $8.6 \%$ & $6.1 \%$ & $45.5 \%$ & $48.5 \%$ \\
\hline 200 to 250 & 4 & 12 & 6 & 22 & $5.7 \%$ & $18.2 \%$ & $54.5 \%$ & $27.3 \%$ \\
\hline 250 to ... & 0 & 13 & 15 & 28 & $7.3 \%$ & $0.0 \%$ & $46.4 \%$ & $53.6 \%$ \\
\hline Total & & & & 383 & & $39.7 \%$ & $30.3 \%$ & $30.0 \%$ \\
\hline
\end{tabular}

Max Depth Cavity: $236.5 \mathrm{ft}$

Max Depth Fracture: $490 \mathrm{ft}$

Max Depth Water: $650 \mathrm{ft}$

\begin{tabular}{|c|c|c|c|c|c|c|c|c|}
\hline \multirow[b]{2}{*}{$\begin{array}{l}\text { Water Depth } \\
\text { Cmn - Wells : }\end{array}$} & \multicolumn{3}{|c|}{ Number of Water Zones Encountered } & \multirow{2}{*}{$\begin{array}{c}\text { Total \# } \\
\text { Water Zones }\end{array}$} & \multirow{2}{*}{$\begin{array}{l}\% \text { Water } \\
\text { by Depth }\end{array}$} & \multicolumn{3}{|c|}{ Percent of Total Water Zones by Depth } \\
\hline & $\begin{array}{l}\text { Cavity } \\
1.500\end{array}$ & Fracture & Water & & & Cavity & Fracture & Water \\
\hline 0 to $25 \mathrm{ft}$ & 3 & 2 & 10 & 15 & $7.7 \%$ & $20.0 \%$ & $13.3 \%$ & $66.7 \%$ \\
\hline 25 to 50 & 17 & 4 & 8 & 29 & $14.9 \%$ & $58.6 \%$ & $13.8 \%$ & $27.6 \%$ \\
\hline 50 to 75 & 17 & 4 & 11 & 32 & $16.4 \%$ & $53.1 \%$ & $12.5 \%$ & $34.4 \%$ \\
\hline 75 to 100 & 4 & 3 & 7 & 14 & $7.2 \%$ & $28.6 \%$ & $21.4 \%$ & $50.0 \%$ \\
\hline 100 to 125 & 2 & 7 & 8 & 17 & $8.7 \%$ & $11.8 \%$ & $41.2 \%$ & $47.1 \%$ \\
\hline 125 to 150 & $\mathbf{0}$ & 5 & 8 & 13 & $6.7 \%$ & $0.0 \%$ & $38.5 \%$ & $61.5 \%$ \\
\hline 150 to 200 & 2 & 13 & 14 & 29 & $14.9 \%$ & $6.9 \%$ & $44.8 \%$ & $48.3 \%$ \\
\hline 200 to 250 & 3 & 12 & 5 & 20 & $10.3 \%$ & $15.0 \%$ & $60.0 \%$ & $25.0 \%$ \\
\hline 250 to ... & 0 & 13 & 13 & 26 & $13.3 \%$ & $0.0 \%$ & $50.0 \%$ & $50.0 \%$ \\
\hline Total & & & & 195 & & $24.6 \%$ & $32.3 \%$ & $43.1 \%$ \\
\hline
\end{tabular}


Table 8. Summary of water breaks by elevation above MSL (based on data from Cmn Picket wells in Shevenell et al., 1992).

\begin{tabular}{|c|c|c|c|c|c|c|}
\hline & $\begin{array}{c}\text { Elevation } \\
0 \mathrm{ft} \text { to } \\
500 \mathrm{ft}\end{array}$ & $\begin{array}{c}\text { Elevation } \\
500 \mathrm{ft} \text { to } \\
600 \mathrm{ft} \\
\end{array}$ & $\begin{array}{c}\text { Elevation } \\
600 \mathrm{ft} \text { to } \\
700 \mathrm{ft}\end{array}$ & $\begin{array}{c}\text { Elevation } \\
700 \mathrm{ft} \text { to } \\
800 \mathrm{ft}\end{array}$ & $\begin{array}{c}\text { Elevation } \\
800 \mathrm{ft} \text { to } \\
900 \mathrm{ft}\end{array}$ & $\begin{array}{c}\text { Elevation } \\
900 \mathrm{ft} \text { to } \\
1000 \mathrm{ft}\end{array}$ \\
\hline Wells Drilled & 4 & 6 & 8 & 15 & 28 & 19 \\
\hline $\begin{array}{l}\text { Total Number } \\
\text { of Fractures }\end{array}$ & 1 & 2 & 5 & 6 & 7 & 3 \\
\hline $\begin{array}{l}\text { Total Number } \\
\text { of Cavities }\end{array}$ & 0 & 0 & 1 & 2 & 11 & 5 \\
\hline $\begin{array}{l}\text { Total of All } \\
\text { Water Zones }\end{array}$ & 19 & 15 & 25 & 60 & 137 & 50 \\
\hline $\begin{array}{l}\% \text { of Total Zones } \\
\text { that are Fractures }\end{array}$ & $5.3 \%$ & $13.3 \%$ & $20.0 \%$ & $10.0 \%$ & $5.1 \%$ & $6.0 \%$ \\
\hline $\begin{array}{l}\% \text { of Total Zones } \\
\text { that are Cavities }\end{array}$ & $0.0 \%$ & $0.0 \%$ & $4.0 \%$ & $3.3 \%$ & $8.0 \%$ & $10.0 \%$ \\
\hline
\end{tabular}

- The total number of wells which penetrate any portion of the elevation interval. 
Table 9. Summary of water zones by well and depth in the Ccr and $\mathrm{Cmn}$.

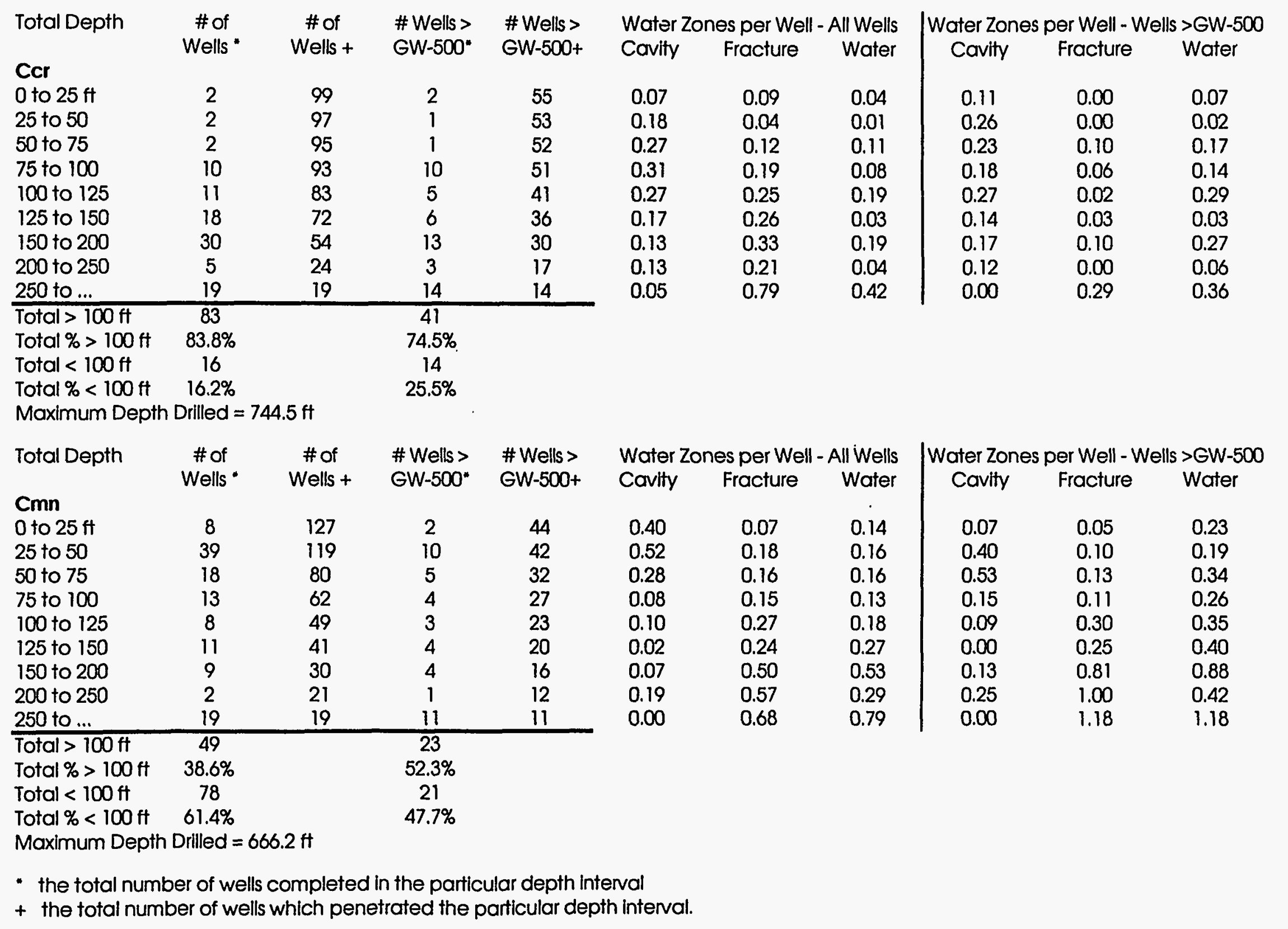


Table 10. Occurrence of cavities in the Cmn.

\begin{tabular}{cccc}
\hline Zone & \# of Wells & $\begin{array}{c}\text { \% of Wells } \\
\text { with Cavities }\end{array}$ & $\begin{array}{c}\text { \% Water Zones } \\
\text { that are Cavities }\end{array}$ \\
\hline Cmn-6 & 12 & 41 & 19 \\
Cmn-5 & 13 & 23 & 17 \\
Cmn-4 & 8 & 12.5 & 25 \\
Cmn-3 & 6 & 0 & 0 \\
Cmn-2 & 10 & 20 & 38 \\
\hline
\end{tabular}

Note: Data are based on data in Shevenell et al. (1992) 
that the data in Table 10 are not directly a function of depth because the Cmn dips at an average angle of $45^{\circ}$. Also, see Tables 4,7 and 8 for differences in data as a function of east-west location, depth and elevation.

The geologic variables which will likely give the best predictive capability were not investigated as part of this study. For instance, there is lithologic and thickness variability between the different zones within the Cmn (Shevenell et al., 1992; Goldstrand, in press), yet these data are only available for a very limited number of wells. If there were more consistent data on grain size, fracture frequency, secondary porosity development, lithologic and mineralogic variability, and variations in zone thicknesses for the separate Cmn zones throughout BCV, these types of data could be incorporated into a statistical model. This additional information would likely be useful in better constraining the occurrence and distribution of conduit locations in the $\mathrm{Cmn}$.

The locations of cavities are likely to be related to several other interacting variables. The following factors are believed to be important in cavity occurrence: (1) location relative to the Cmn subcrop, (2) location relative to major springs, sinkholes and faults and fractures, (3) location relative to cross cutting valleys (strike perpendicular valleys). Data for item (2) is unknown in many cases (ie. faults and fractures) when referring to these characteristics in relation to particular water zones encountered at depth, and would be of little use in GLM and LOG models. However, the locations of springs, sinkholes, and cross cutting valleys are relatively well known, and the distance and bearing of known conduits to these features could be incorporated into LOG and GLM type models. Perhaps the addition of these types of data would improve the results of a LOG or GLM model. These data could also be used to qualitatively estimate cavity location.

\section{CONCLUSIONS AND RECOMMENDATIONS}

The General Linear Models and Logistic Regression Models formulated were not successful in adequately predicting cavity size or the probability of cavity occurrence at specific locations within the Ccr and Cmn. In the LOG models, the East and North coordinates were not significant variables in the Ccr data, and the East coordinate was not a significant variable in the Cmn data set. Hence, with a given Elev, Loc, and North value, cavity presence would be independent of the East value in the Cmn. The model is insensitive to the east coordinate, which is reasonable given that the dominant flow direction in the $\mathrm{Cmn}$ is along strike (E-W). Both GLM and LOG analyses suggest that cavity size and presence in Cmn is a strong function of North and Elev (or Depth).

Models were constructed for all water intervals in both the Cmn and Ccr, and for each unit separately. The model results were consistently different between the $\mathrm{Cmn}$ and $\mathrm{Ccr}$. The fact that the $\mathrm{Ccr}$ and $\mathrm{Cmn}$ data sets appear to produce different models is not surprising considering the hydrogeology of the two differs. Flow in the Cmn is generally at elevations between 600 and $950 \mathrm{ft}$ and is dominantly strike parallel through submerged, partially mud-filled cavities with sizes up to $40 \mathrm{ft}$ in diameter, but more typically less than $5 \mathrm{ft}$. Recognized flow in the Ccr is generally above an elevation of $950 \mathrm{ft}$ with flow both parallel and perpendicular to geologic strike through conduits which tend to be larger, and are often not fully saturated at the shallower depths.

A subset of the full data set which included the depth below lithologic contact (DBC) variable was used some estimation procedures. In the 39 observation Ccr data subset including DBC, East, Loc and East*Loc were usually the dominant variables, whereas North was also of importance in the larger data set. Elev and East*Loc were the dominant variables in the 133 observation subset of Cmn data. Elev, Elev*Elev, $\mathrm{N} * \mathrm{Elev}$, and north*north were dominant in the complete data set. Numerous differences between the data sets occur and it is clear that the smaller data sets are not representative subsets of the full data set.

All available spatial data were used to construct logistic regression models, and a secondary data set, which was much smaller and eliminated questionable data collected prior to 1987 , was used in an attempt to find a suitable model. An insufficient number of variables were found to be important in 
explaining the observed variability in the data sets in both the $\mathrm{Ccr}$ and $\mathrm{Cmn}$. For instance, the resulting model for Cmn is not a strong function of East coordinates, and the Ccr model is not a strong function of either the North or East coordinates. Hence, the presence or absence of a cavity at a given location can not be predicted because not all variables that define a point in space are significant. Given the complexities of the karst aquifers and limited resources available to fully identify cavity locations and characterize relevant hydrologic and geologic parameters, it is possible that logistic and GLM models will be inadequate in predicting cavity occurrence based on the variables used in the current models regardless of the amount of additional data that may be acquired from drilling. Perhaps some of the information presented in this report could be incorporated into $2-\mathrm{D}$ or 3-D probability plots which may provide some insight into future modeling efforts.

Although the models were unsuccessful in providing a means of adequately predicting the cavity size or probability of cavity occurrence in the $\mathrm{Ccr}$ and $\mathrm{Cmn}$, ongoing work in the $\mathrm{Cmn}$ may provide additional information which can be incorporated into future models. Variables such as lithology, stratigraphy, mineralogy, and bed thicknesses could have been very useful in constraining the models, yet detailed geologic information is not available at most well locations. Intervals of quick flow through the Ccr and Cmn have been identified with the use of geochemical data (Shevenell, in press) and this information could be used to condition the existing cavity location data. Cross borehole testing and long-term water level, temperature and specific conductance monitoring are providing data to evaluate directional characteristics of hydraulically active conduits, and response times to precipitation events in several locations throughout the study area. The hydrologic characteristics of the conduits may be useful in constructing more representative models by using this information to condition and weight the location data.

Numerous other controlling variables were not included in the model due to lack of data at many of the locations. For instance, the presence or absence of a cavity is likely to be a function of lithology, zone thicknesses, and matrix and secondary porosity values, and such variables would give and indication of the ease of dissolution and likelihood of cavity occurrence. These types of data could be examined on localized areas where data are available, but were not considered in this report because these data are not known in detail at most well bore locations. Numerous studies show that zone 2 of the Cmn is very likely to contain cavities, particularly at shallow depths (Shevenell et al., 1992; Goldstrand, in press). Ongoing work on matrix and secondary porosity development in the Cmn and Car (Goldstrand, in press; Goldstrand et al. in prep) will provide additional information on the lithologic zones, and depth control on conduit development in this karst aquifer which will be useful in formulating future models. Goldstrand (in press) indicate that important controls on secondary porosity development are dissolution of gypsum, dedolomitization, carbonate grain-size (with finer grain sizes being subject to greater dissolution), and oxidation of pyrite. Simply location data are not sufficient to identify the probability of cavity occur-

rence. Hydrologic, geologic, and geochemical data and interpretations must be incorporated into future modeling efforts in order to obtain a better prediction of cavity location as a function of all relevant variables.

\section{ACKNOWLEDGMENTS}

We wish to thank W. Kevin Jago and Gerilynn Moline for useful discussions regarding this work. The technical reviews provided by Craig Rightmire and David Watson are appreciated.

\section{REFERENCES}

Dreier, R.B., T.O. Early, and H.L. King, 1993, Results and interpretation of groundwater data obtained from multiport-instrumented coreholes (GW-131 through GW-135), Fiscal Years 1990 and 1991, Y/TS-803.

Geraghty and Miller, Inc., 1990, Comprehensive groundwater monitoring plan for the Oak Ridge Y-12 Plant, Y/SUB/90-00206C/5. 
Goldstrand, P.M, (in press), Stratigraphic variations and secondary porosity within the Maynardville Limestone in Bear Creek Valley, Y-12 Plant, Oak Ridge, Tennessee, Y-12 Plant Report, Y/TS-1093.

Goldstrand, P.M., Dreier, R.B., and Menefee, L., (in prep.) Porosity development in the Copper Ridge Dolomite and Maynardville Limestone, Bear Creek Valley, Tennessee, Y-12 Report.

Hatcher, R.D., Jr., et al., 1992, Status Report on the Geology of the Oak Ridge Reservation, ORNL/TM-12074

Jago, W.K., 1993, personal communication, Health, Safety, Environmental and Accountability Organization, Oak Ridge Y-12 Plant.

Jones, S.B., B.K. Harrington, and S.M. Field, 1992, Updated subsurface data base for Bear Creek Valley, Chestnut Ridge, and parts of Bethel Valley on the U.S. Department of Energy Oak Ridge Reservation, Y/TS-881.

Lemiszki, P, and P. Rubin, 1993, personal communication, Environmental Sciences Division, Oak Ridge National Laboratory.

Pregibon, D., 1981, Logistic Regression Diagnostics, Annals of Statistics, vol. 9, p. 705-724.

SAS Institute Inc., 1992, SAS/STAT User's Guide, Version 6, Fourth Edition, Volume 2, Cary, NC.

Shevenell, L., (in press), Chemical characteristics of waters in karst formations at the Oak Ridge Y-12 Plant, Y/TS-1001.

Shevenell, L., R.B. Dreier, and W.K. Jago, 1992, Summary of fiscal years 1991 and 1992 construction, hydrologic and geologic data obtained from the Maynardville Limestone exit pathway monitoring program, Y/TS-814. 


\section{APPENDICES}

Appendix A. Listing of water zones in the $\mathrm{Cmn}$ and $\mathrm{Ccr}$ used in this report

Appendix B. Selected GLM model results for both transformed and non-transformed data.

Appendix C. Comparison of selected GLM model results with and without the use of the DBC variable.

Appendix D. Summary of selected logistic model results. Variables are transformed unless otherwise noted. 
Appendix A: List of water zones in the Gmn and Ccr used in this report.

A zone type of 0 refers to fractures and water zones, and 1 refers to cavities. Location indicates the well location on a ridge $(\mathrm{A})$, or hill $(\mathrm{H})$, or in a valley $(\mathrm{M})$. A $\because$ entry indicates no data are available

\begin{tabular}{|c|c|c|c|c|c|c|c|}
\hline $\begin{array}{l}\text { Well } \\
\text { Number }\end{array}$ & Type & Loc & $\begin{array}{c}\text { Size } \\
\text { (ft) }\end{array}$ & $\begin{array}{c}\text { Easting } \\
(\mathrm{ft})\end{array}$ & $\begin{array}{c}\text { Northing } \\
\text { (fi) }\end{array}$ & $\begin{array}{c}\text { Depth } \\
\text { Water (t) }\end{array}$ & $\begin{array}{l}\text { Elevation } \\
\text { Water (ft) }\end{array}$ \\
\hline \multicolumn{8}{|c|}{ Copper Ridge Dolomite } \\
\hline 1084 & 0 & $\mathbf{H}$ & 0.00 & 53599 & 25008 & 120.00 & 84224 \\
\hline 1085 & 1 & $\mathbf{H}$ & 5.00 & 52997 & 26097 & 86.00 & 944.73 \\
\hline 1085 & 0 & $H$ & 0.00 & 52997 & 26097 & 112.00 & 918.73 \\
\hline 1086 & 1 & $H$ & 2.00 & 52316 & 26923 & 99.00 & 993.10 \\
\hline 1086 & 1 & $\mathbf{H}$ & 2.00 & 52316 & 26923 & 124.00 & 968.10 \\
\hline 1086 & 0 & $H$ & 0.00 & 52316 & 26923 & 140.00 & 952.10 \\
\hline 1087 & 1 & $H$ & 4.50 & 52289 & 25817 & 72.50 & 931.63 \\
\hline 1087 & 0 & $\mathrm{H}$ & 0.00 & 52289 & 25817 & 130.00 & 874.13 \\
\hline GW-099 & 0 & $\mathbf{R}$ & 0.00 & 52074 & 28495 & 86.00 & 1092.67 \\
\hline GW-099 & 0 & $\mathbf{R}$ & 0.00 & 52074 & 28495 & 112.00 & 1066.67 \\
\hline GW-141 & 1 & $\mathbf{R}$ & . & 52463 & 28755 & 145.50 & 1037.95 \\
\hline$G W-141$ & 0 & $\mathbf{R}$ & 0.00 & 52463 & 28755 & 120.00 & 1063.45 \\
\hline$G W-141$ & 0 & $R$ & 0.00 & 52463 & 28755 & 145.00 & 1038.45 \\
\hline GW-147 & 0 & $R$ & 0.00 & 63428 & 24731 & 10.00 & 838.41 \\
\hline GW-147 & 0 & $\mathbf{R}$ & 0.00 & 63428 & 24731 & 19.00 & 829.41 \\
\hline GW-147 & 0 & $\mathbf{R}$ & 0.00 & 63428 & 24731 & 20.00 & 828.41 \\
\hline GW-147 & 0 & $\mathbf{R}$ & 0.00 & 63428 & 24731 & 24.00 & 824.41 \\
\hline$G W-147$ & 0 & $\mathbf{R}$ & 0.00 & 63428 & 24731 & 32.50 & 815.91 \\
\hline GW-147 & 0 & $\mathbf{R}$ & 0.00 & 63428 & 24731 & 46.50 & 801.91 \\
\hline GW-147 & 0 & $R$ & 0.00 & 63428 & 24731 & 59.50 & 788.91 \\
\hline GW-155 & 0 & $\mathbf{R}$ & 0.00 & 64333 & 27722 & 130.00 & 928.88 \\
\hline GW-155 & 0 & $\mathbf{R}$ & 0.00 & 64333 & 27722 & 165.00 & 893.88 \\
\hline GW-156 & 1 & R & 1.00 & 64020 & $27 \approx 26$ & 92.00 & 954.94 \\
\hline GW-156 & 1 & $R$ & 2.00 & 64020 & 27626 & 101.00 & 945.94 \\
\hline GW-156 & 1 & $\mathbf{R}$ & 6.00 & 64020 & $27 œ 26$ & 106.00 & 940.94 \\
\hline GW-156 & 0 & $\mathbf{R}$ & 0.00 & 64020 & 27626 & 150.00 & 896.94 \\
\hline GW-157 & 0 & $\mathbf{R}$ & 0.00 & 63892 & 27477 & 74.00 & 970.85 \\
\hline GW-157 & 0 & $\mathbf{R}$ & 0.00 & 63892 & 27477 & 114.00 & 930.85 \\
\hline GW-157 & 0 & $\mathbf{R}$ & 0.00 & 63892 & 27477 & 140.00 & 904.85 \\
\hline GW-158 & 0 & $\mathbf{R}$ & 0.00 & 63643 & 27069 & 98.00 & 88324 \\
\hline$G W-158$ & 0 & $\mathbf{R}$ & 0.00 & 63643. & 27069 & 180.00 & 801.24 \\
\hline GW-158 & 0 & $\mathbf{R}$ & 0.00 & 63643 & 27069 & 220.00 & 761.24 \\
\hline GW-158 & 0 & $R$ & 0.00 & 63643 & 27069 & 250.00 & 73124 \\
\hline GW-159 & 1 & $\mathbf{R}$ & 5.00 & 63496 & 27764 & 112.00 & 986.79 \\
\hline GW-159 & 0 & $\mathbf{R}$ & 0.00 & 63496 & 27764 & 130.00 & 918.79 \\
\hline$G W-160$ & 1 & $R$ & . & 62165 & 27803 & 111.00 & 979.66 \\
\hline$G W-160$ & 1 & $\mathbf{R}$ & 3.00 & 62165 & 27803 & 115.00 & 975.66 \\
\hline GW-160 & 1 & $\mathbf{R}$ & 3.00 & 62165 & 27803 & 137.00 & 953.66 \\
\hline GW-160 & 1 & $\mathbf{R}$ & 2.00 & 62165 & 27803 & 169.00 & 921.66 \\
\hline GW-160 & 1 & $\mathbf{R}$ & 3.00 & 62165 & 27803 & 221.00 & 869.66 \\
\hline$G W-160$ & 0 & R & 0.00 & 62165 & 278003 & 112.00 & 978.66 \\
\hline GW-160 & 0 & $\mathbf{R}$ & 0.00 & 62165 & 27803 & 118.00 & 972.66 \\
\hline GW-160 & 0 & $\mathbf{R}$ & 0.00 & 62165 & 27803 & 160.00 & 930.66 \\
\hline GW-160 & 0 & R & 0.00 & 62165 & 27803 & 171.00 & 919.66 \\
\hline GW-161 & 0 & $R$ & 0.00 & 62146 & 27805 & 98.00 & 992.91 \\
\hline GW-161 & 0 & R & 0.00 & 62146 & 27805 & 140.00 & 950.91 \\
\hline GW-161 & 0 & $\mathbf{R}$ & 0.00 & 62146 & 27805 & 170.00 & 920.91 \\
\hline GW-161 & 0 & $\mathbf{R}$ & 0.00 & 62146 & 27805 & 218.00 & 872.91 \\
\hline GW-161 & 0 & $\mathbf{R}$ & 0.00 & 62146 & 27805 & 236.00 & 854.91 \\
\hline GW-161 & 0 & $\mathbf{R}$ & 0.00 & 62146 & 27805 & 314.00 & 776.91 \\
\hline GW-161 & 0 & $\mathbf{R}$ & 0.00 & 62146 & 27805 & 362.00 & 728.91 \\
\hline GW-161 & 0 & $R$ & 0.00 & 62146 & 27805 & 370.00 & 720.91 \\
\hline GW-165 & 1 & $\mathbf{R}$ & 10.00 & 44547 & 27807 & 103.00 & 987.39 \\
\hline GW-165 & 1 & $\mathbf{R}$ & 3.00 & 44547 & 27807 & 314.00 & 776.39 \\
\hline
\end{tabular}




\begin{tabular}{|c|c|c|c|c|c|c|c|}
\hline $\begin{array}{l}\text { Well } \\
\text { Number }\end{array}$ & Type & Loc & $\begin{array}{c}\text { Size } \\
\text { (fi) }\end{array}$ & $\begin{array}{c}\text { Easting } \\
\text { (ft) }\end{array}$ & $\begin{array}{l}\text { Northing } \\
\text { (fi) }\end{array}$ & $\begin{array}{c}\text { Depth } \\
\text { Water (ft) }\end{array}$ & $\begin{array}{l}\text { Elevation } \\
\text { Water (t) }\end{array}$ \\
\hline GW-165 & 0 & R & 0.00 & 44547 & 27807 & 92.00 & 998.39 \\
\hline GW-165 & 0 & $\mathbf{R}$ & 0.00 & 44547 & 27807 & 100.00 & 990.39 \\
\hline GW-165 & 0 & $\mathbf{A}$ & 0.00 & 44547 & 27807 & 312.00 & 778.39 \\
\hline GW-166 & 0 & R & 0.00 & 44531 & 27835 & 287.00 & 805.01 \\
\hline GW-166 & o & $\mathbf{A}$ & 0.00 & 44531 & 27835 & 320.00 & 772.01 \\
\hline GW-166 & 0 & A & 0.00 & 44531 & 27835 & 323.00 & 769.01 \\
\hline GW-173 & 1 & $\mathbf{R}$ & . & 59472 & 28271 & 108.90 & 1004.07 \\
\hline$G W-173$ & 1 & A & 1.00 & 59472 & 28271 & 140.00 & 972.97 \\
\hline GW-173 & 0 & $\mathbf{R}$ & 0.00 & 59472 & 28271 & 103.60 & 100937 \\
\hline GW-174 & 1 & R & 16.60 & 59215 & 28205 & 63.00 & $105 t .06$ \\
\hline GW-174 & 1 & R & . & 59215 & 28205 & 91.00 & 1023.06 \\
\hline GW-174 & 1 & $\mathbf{R}$ & . & 59215 & 28205 & 140.00 & 974.06 \\
\hline GW-174 & 0 & $\mathbf{R}$ & 0.00 & 59215 & 28205 & 143.00 & 971.06 \\
\hline GW-175 & 1 & $\mathbf{R}$ & • & 58686 & 28676 & 85.00 & 996.89 \\
\hline GW-175 & 0 & $\mathbf{A}$ & 0.00 & 58686 & 28676 & 125.00 & 956.89 \\
\hline GW-175 & 0 & R & 0.00 & 58686 & 28676 & 160.00 & 921.89 \\
\hline GW-175 & 0 & $\mathbf{R}$ & 0.00 & 58586 & 28576 & 161.00 & 920.89 \\
\hline GW-177 & 1 & $\mathbf{R}$ & 5.00 & 57497 & 28483 & 68.00 & 1087.52 \\
\hline GW-177 & 1 & R & 1.50 & 57497 & 28483 & 96.00 & 1059.52 \\
\hline GW-177 & 0 & $\mathbf{R}$ & 0.00 & 57497 & 28483 & 130.00 & 1025.52 \\
\hline GW-178 & 1 & R & • & 57808 & 28552 & 43.00 & 1098.06 \\
\hline GW-178 & 1 & $R$ & - & 57808 & 28552 & 45.50 & 1095.56 \\
\hline GW-178 & 1 & $\mathbf{R}$ & . & 57808 & 28552 & 52.00 & 1089.06 \\
\hline GW-178 & 1 & $\mathbf{R}$ & . & 57808 & 28552 & 58.00 & 1083.06 \\
\hline GW-178 & 1 & R & . & 57808 & 28552 & 64.00 & 1077.06 \\
\hline GW-178 & 1 & $\mathbf{R}$ & . & 57808 & 28552 & 82.00 & 1059.06 \\
\hline$G W-178$ & 0 & $\mathbf{R}$ & 0.00 & 57808 & 28552 & 74.00 & 1067.06 \\
\hline GW-178 & 0 & R & 0.00 & 57808 & 28552 & 80.00 & 1061.06 \\
\hline GW-178 & 0 & R & 0.00 & 57808 & 28552 & 81.00 & 1060.06 \\
\hline GW-178 & 0 & R & 0.00 & 57808 & 28552 & 84.00 & 1057.06 \\
\hline GW-178 & 0 & $\mathbf{A}$ & 0.00 & 57808 & 28552 & 90.00 & 1051.06 \\
\hline GW-178 & 0 & R & 0.00 & 57808 & 28552 & 100.00 & 1041.06 \\
\hline GW-178 & 0 & $\mathbf{A}$ & 0.00 & 57808 & 28552 & 106.00 & 1035.06 \\
\hline GW-178 & 0 & A & 0.00 & 57808 & 28552 & 121.00 & 1020.06 \\
\hline GW-178 & 0 & $\mathbf{R}$ & 0.00 & 57808 & 28552 & 125.00 & 1016.06 \\
\hline GW-179 & 1 & $\mathbf{R}$ & 19.60 & 58569 & 28522 & 53.00 & 107133 \\
\hline GW-179 & 0 & $\mathbf{R}$ & 0.00 & 58569 & 28522 & 112.00 & 101233 \\
\hline GW-180 & 1 & $\mathbf{A}$ & . & 59220 & 28494 & 58.00 & 1043.43 \\
\hline$G W-180$ & 1 & $\mathbf{R}$ & . & 59220 & 28494 & 68.00 & 1033.43 \\
\hline GW-180 & 1 & $\mathbf{R}$ & . & 59220 & 28494 & 78.00 & 1023.43 \\
\hline GW-180 & 1 & A & . & 59220 & 28494 & 81.00 & 1020.43 \\
\hline$G W-180$ & 1 & $\mathbf{R}$ & . & 59220 & 28494 & 83.00 & 1018.43 \\
\hline GW-180 & 1 & $\mathbf{R}$ & . & 59220 & 28494 & 85.00 & 1016.43 \\
\hline GW-180 & 0 & R & 0.00 & 59220 & 28494 & 97.00 & 1004.43 \\
\hline GW-180 & 0 & $\mathbf{R}$ & 0.00 & 59220 & 28494 & 132.00 & 969.43 \\
\hline GW-181 & 1 & $\mathbf{R}$ & 2.00 & 57736 & 28048 & 147.00 & 943.55 \\
\hline GW-217 & 0 & $R$ & 0.00 & 53020 & 28758 & 125.00 & 1049.29 \\
\hline GW-217 & 0 & $\mathbf{R}$ & 0.00 & 53020 & 28758 & 165.00 & 100929 \\
\hline GW-221 & 0 & $\mathbf{R}$ & 0.00 & 54389 & 28359 & 36.00 & 1067.36 \\
\hline GW-221 & 0 & $\mathbf{R}$ & 0.00 & 54389 & 28359 & 153.00 & 95036 \\
\hline GW-231 & 0 & $H$ & 0.00 & 63410 & 24725 & 15.00 & 831.90 \\
\hline GW-231 & 0 & H & 0.00 & 63410 & 24725 & 17.00 & 829.90 \\
\hline GW-231 & 0 & $\mathbf{H}$ & 0.00 & 63410 & 24725 & 19.00 & 827.90 \\
\hline GW-231 & 0 & $H$ & 0.00 & 63410 & 24725 & 23.00 & 823.90 \\
\hline GW-231 & 0 & H & 0.00 & 63410 & 24725 & 25.00 & 821.90 \\
\hline GW-231 & 0 & $H$ & 0.00 & 63410 & 24725 & 28.00 & 818.90 \\
\hline GW-233 & 1 & $\mathbf{R}$ & - & 52596 & 28415 & 130.00 & 1049.44 \\
\hline GW-233 & 0 & $\mathbf{R}$ & 0.00 & 52596 & 28415 & 127.00 & 1052.44 \\
\hline GW-233 & 0 & $\mathbf{R}$ & 0.00 & 52596 & 28415 & 134.00 & 1045.44 \\
\hline GW-233 & 0 & $\mathbf{R}$ & 0.00 & 52596 & 28415 & 154.50 & 1024.94 \\
\hline GW-233 & 0 & R & 0.00 & 52596 & 28415 & 149.00 & 1030.44 \\
\hline GW-233 & 0 & $\mathbf{A}$ & 0.00 & 52596 & 28415 & 167.00 & 1012.44 \\
\hline
\end{tabular}




\begin{tabular}{|c|c|c|c|c|c|c|c|}
\hline $\begin{array}{l}\text { Well } \\
\text { Number }\end{array}$ & Type & Loc & $\begin{array}{c}\text { Size } \\
\text { (ft) }\end{array}$ & $\begin{array}{l}\text { Easting } \\
\text { (ft) }\end{array}$ & $\begin{array}{l}\text { Northing } \\
\text { (ii) }\end{array}$ & $\begin{array}{l}\text { Depth } \\
\text { Water (ft) }\end{array}$ & $\begin{array}{l}\text { Elevation } \\
\text { Water }(\mathrm{t})\end{array}$ \\
\hline GW-241 & 1 & R & 11.00 & ๘659 & 27069 & 78.00 & 902.80 \\
\hline GW-241 & 0 & R & 0.00 & 63659 & 27069 & 89.00 & 891.80 \\
\hline GW-292 & 1 & $H$ & 1.50 & 62146 & 28141 & 56.50 & 1013.61 \\
\hline GW-292 & 1 & $\mathrm{H}$ & 2.50 & $œ 2146$ & 28141 & 93.00 & 977.11 \\
\hline GW-292 & o & $H$ & 0.00 & 62146 & 28141 & 58.00 & 1012.11 \\
\hline GW-292 & 0 & H & 0.00 & 62146 & 28141 & 66.00 & 1004.11 \\
\hline GW-292 & 0 & $\mathrm{H}$ & 0.00 & $œ 2146$ & 28141 & 177.00 & 893.11 \\
\hline GW-298 & 1 & R & 3.00 & 62321 & 28112 & 107.00 & 954.70 \\
\hline GW-298 & 0 & $\mathbf{R}$ & 0.00 & 62321 & 28112 & 59.00 & 1002.70 \\
\hline GW-293 & o & $\mathbf{R}$ & 0.00 & 62321 & 28112 & 206.00 & 855.70 \\
\hline GW-294 & 0 & R & 0.00 & $œ 483$ & 27958 & 62.00 & 1019.74 \\
\hline GW-295 & 1 & A & 2.01 & $œ 184$ & 27802 & 137.00 & 953.42 \\
\hline GW-295 & 0 & A & 0.00 & 62184 & 27802 & 110.00 & 980.42 \\
\hline GW-295 & 0 & R & 0.00 & 62184 & 27802 & 115.00 & 975.42 \\
\hline GW-295 & 0 & R & 0.00 & 62184 & 27802 & 120.00 & 970.42 \\
\hline GW-295 & 0 & $\mathbf{R}$ & 0.00 & 62184 & 27802 & 135.00 & 955.42 \\
\hline GW-297 & 1 & R & . & 62057 & 27885 & 81.00 & 1017.88 \\
\hline GW-297 & 1 & $\mathbf{R}$ & . & 62057 & 27885 & 93.00 & 1005.88 \\
\hline GW-298 & 1 & $\mathbf{R}$ & . & 62445 & 27495 & 90.00 & 956.40 \\
\hline GW-298 & 0 & $\mathbf{R}$ & 0.00 & $œ 445$ & 27495 & 179.00 & 867.40 \\
\hline GW-298 & 0 & $\mathbf{R}$ & 0.00 & $œ 245$ & 27495 & 182.00 & 864.40 \\
\hline GW-299 & 0 & $\mathbf{R}$ & 0.00 & 62319 & 27392 & 132.00 & 919.33 \\
\hline GW-299 & 0 & $\mathbf{R}$ & 0.00 & 62319 & 27392 & 156.00 & 89533 \\
\hline GW-300 & 0 & $\mathbf{R}$ & 0.00 & 62041 & 27487 & 141.00 & 929.69 \\
\hline GW-301 & 1 & $\mathbf{R}$ & & 61964 & 27602 & 98.50 & 990.44 \\
\hline GW-301 & 1 & $\mathbf{R}$ & 15.00 & 61964 & 27662 & 121.00 & 962.94 \\
\hline GW-301 & 0 & $\mathbf{R}$ & 0.00 & 61964 & 27662 & 109.00 & 974.94 \\
\hline GW-301 & 0 & $\mathbf{R}$ & 0.00 & 61984 & 27662 & 118.00 & 965.94 \\
\hline GW-301 & 0 & $\mathbf{R}$ & 0.00 & 61964 & 27662 & 154.00 & 929.94 \\
\hline GW-302 & 1 & $\mathbf{R}$ & 3.00 & 54353 & 28694 & 70.00 & 1069.59 \\
\hline GW-302 & 1 & $\mathbf{R}$ & 2.00 & 54353 & 28694 & 86.00 & 1053.59 \\
\hline GW-302 & 0 & $\mathbf{R}$ & 0.00 & 54353 & 28694 & 127.00 & 1012.59 \\
\hline GW-302 & 0 & $\mathbf{R}$ & 0.00 & 54353 & 28694 & 131.00 & 1008.59 \\
\hline GW-302 & 0 & $\mathbf{R}$ & 0.00 & 54353 & 28694 & 99.80 & 1039.79 \\
\hline GW-303 & 1 & $\mathbf{R}$ & . & 63488 & 28099 & 39.00 & 965.44 \\
\hline GW-303 & 1 & $\mathbf{R}$ & & 63488 & 28099 & 109.00 & 895.44 \\
\hline GW-303 & 0 & $\mathbf{R}$ & 0.00 & 63488 & 28099 & 258.00 & 746.44 \\
\hline GW-303 & 0 & $\mathbf{R}$ & 0.00 & $\mathbf{6 3 4 8 8}$ & 28099 & 302.00 & 702.44 \\
\hline GW-303 & 0 & $\mathbf{R}$ & 0.00 & $\$ 488$ & 28099 & 310.00 & 694.44 \\
\hline GW-305 & 0 & $\mathbf{R}$ & 0.00 & 52962 & 28548 & 169.00 & 1012.07 \\
\hline GW-322 & 1 & $\mathbf{R}$ & 20.00 & 58912 & 28241 & 98.00 & 1033.81 \\
\hline GW-322 & 1 & $\mathbf{R}$ & 2.00 & 58912 & 28241 & 188.00 & 943.81 \\
\hline GW-322 & 0 & R & 0.00 & 58912 & 28241 & 83.00 & 1048.81 \\
\hline GW-322 & 0 & $\mathbf{R}$ & 0.00 & 58912 & 28241 & 125.00 & 1006.81 \\
\hline GW-323 & 0 & A & 0.00 & 52106 & 28985 & 97.00 & 1030.41 \\
\hline GW-323 & 0 & $\mathbf{R}$ & 0.00 & 52106 & 28985 & 100.50 & 1026.91 \\
\hline GW-323 & 0 & $\mathbf{R}$ & 0.00 & 52106 & 28985 & 106.50 & 1020.91 \\
\hline GW-339 & 1 & $\mathbf{R}$ & . & 54147 & 28659 & 54.00 & 1068.18 \\
\hline GW-339 & 1 & $\mathbf{R}$ & . & 54147 & 28659 & 67.00 & 1055.18 \\
\hline GW-339 & 1 & $\mathbf{R}$ & & 54147 & 28659 & 82.00 & 1040.18 \\
\hline GW-339 & 0 & $\mathbf{R}$ & 0.00 & 54147 & 28659 & 107.00 & 1015.18 \\
\hline GW-511 & 1 & $\mathbf{A}$ & 2.00 & 57739 & 28056 & 85.00 & 1005.70 \\
\hline GW-511 & 1 & $\mathbf{R}$ & & 57739 & 28056 & 152.00 & $\mathbf{9 3 8 . 7 0}$ \\
\hline GW-513 & 1 & $H$ & 7.00 & 57332 & 27607 & 75.00 & 923.99 \\
\hline GW-513 & 1 & H & 5.00 & 57332 & 27607 & $\mathbf{9 2 . 0 0}$ & 906.99 \\
\hline GW-514 & 1 & H & 3.70 & 57341 & 27575 & 44.30 & 95436 \\
\hline GW-514 & 1 & H & 12.00 & 57341 & 27575 & 78.00 & 920.66 \\
\hline GW-514 & 1 & $H$ & 1.00 & 57341 & 27575 & 157.00 & 841.66 \\
\hline GW-521 & 1 & $\mathbf{R}$ & 2.00 & 52040 & 28541 & 127.00 & 1052.46 \\
\hline GW-522 & 1 & $\mathbf{R}$ & 2.00 & 52612 & 28377 & 102.00 & 1070.04 \\
\hline GW-522 & 1 & $\mathbf{R}$ & . & 52612 & 28377 & 116.00 & 1056.04 \\
\hline GW-539 & 0 & $H$ & 0.00 & 52278 & 27193 & 11.00 & 1079.39 \\
\hline
\end{tabular}




\begin{tabular}{|c|c|c|c|c|c|c|c|}
\hline $\begin{array}{l}\text { Well } \\
\text { Number }\end{array}$ & Type & $L O C$ & $\begin{array}{l}\text { Size } \\
\text { (it) }\end{array}$ & $\begin{array}{l}\text { Easting } \\
\text { (fi) }\end{array}$ & $\begin{array}{l}\text { Northing } \\
\text { (ii) }\end{array}$ & $\begin{array}{c}\text { Depth } \\
\text { Water (fi) }\end{array}$ & $\begin{array}{l}\text { Elevation } \\
\text { Water (ft) }\end{array}$ \\
\hline GW-539 & 0 & $H$ & 0.00 & 52278 & 27193 & 155.00 & 935.39 \\
\hline GW-540 & 1 & $H$ & 7.00 & 52371 & 27489 & 125.00 & 944,38 \\
\hline GW-540 & 1 & H & 4.00 & 52371 & 27489 & 139.00 & 930.38 \\
\hline GW-541 & 1 & H & 0.50 & 51738 & 27654 & 69.00 & 986.79 \\
\hline GW-542 & 0 & H & 0.00 & 51642 & 27466 & 73.00 & 976.03 \\
\hline GW-543 & 0 & H & 0.00 & 51458 & 27072 & 86.00 & 905.19 \\
\hline GW-544 & 0 & H & 0.00 & 51820 & 26963 & 104.00 & 938.53 \\
\hline GW-544 & 0 & H & 0.00 & 51820 & 26963 & 107.00 & $\mathbf{9 3 5 . 5 3}$ \\
\hline GW-545 & 0 & H & 0.00 & 51729 & 27641 & 55.00 & 1000.43 \\
\hline GW-545 & 0 & H & 0.00 & 51729 & 27641 & 59.00 & 996.43 \\
\hline GW-546 & 0 & H & 0.00 & 52366 & 27474 & 72.50 & 997.14 \\
\hline GW-546 & 0 & H & 0.00 & 52366 & 27474 & 82.50 & 987.14 \\
\hline GW-551 & 1 & H & & 60263 & 27299 & 122.00 & 868.36 \\
\hline GW-551 & 1 & H & 22.40 & 60263 & 27299 & 122.60 & 867.76 \\
\hline GW-551 & 1 & H & 1.40 & 60263 & 27299 & 213.00 & 77736 \\
\hline GW-554 & 1 & H & 0.90 & 61288 & 25356 & 102.60 & 804.20 \\
\hline GW-555 & 1 & H & 5.00 & 59851 & 25868 & 75.00 & 859.91 \\
\hline GW-558 & 1 & H & . & 58949 & 26104 & 50.00 & 931.41 \\
\hline GW-561 & 1 & $\mathbf{R}$ & 7.40 & 59923 & 27811 & 56.40 & 974.34 \\
\hline GW-607 & 0 & R & 0.00 & 58922 & 27866 & 143.00 & 929.86 \\
\hline GW-608 & 1 & $\mathbf{R}$ & 21.00 & 59724 & 27889 & 114.00 & 957.00 \\
\hline GW-608 & 1 & $\mathbf{R}$ & 2.00 & 59724 & 27889 & 216.00 & 855.00 \\
\hline GW-609 & 1 & $\mathbf{R}$ & 4.50 & 60040 & 28109 & 125.00 & 984.70 \\
\hline GW-609 & 0 & $\mathbf{R}$ & 0.00 & 60040 & 28109 & 97.00 & 1012.70 \\
\hline GW-610 & 1 & R & 8.00 & 59472 & 28549 & 55.00 & 1001.78 \\
\hline GW-611 & 1 & H & 5.00 & 58059 & 28856 & 55.00 & 990.43 \\
\hline GW-611 & 0 & H & 0.00 & 58059 & 28856 & 85.00 & 960.43 \\
\hline GW-612 & 1 & $\mathbf{R}$ & 3.00 & 58504 & 28371 & 81.00 & 1047.65 \\
\hline GW-612 & 1 & $\mathbf{R}$ & 15.50 & 58504 & 28371 & 104.00 & 1024.65 \\
\hline GW-672 & 0 & H & 0.00 & 57042 & 26269 & 11.50 & 915.23 \\
\hline GW-673 & 1 & H & 1.00 & 56904 & 25567 & 120.00 & 760.20 \\
\hline GW-673 & 0 & H & 0.00 & 56904 & 25567 & 123.00 & 75720 \\
\hline GW-674 & o & H & 0.00 & 56911 & 25578 & 5.00 & 875.23 \\
\hline GW-676 & 0 & H & 0.00 & 56563 & 24226 & 7.00 & 836.02 \\
\hline GW-677 & 0 & H & 0.00 & 56260 & 27484 & 30.00 & 997.80 \\
\hline GW-677 & 0 & H & 0.00 & 56250 & 27484 & 152.00 & 875.80 \\
\hline GW-678 & 1 & H & 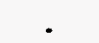 & 56462 & 27415 & 130.00 & 868.10 \\
\hline GW-679 & 0 & H & 0.00 & 56766 & 27267 & 115.00 & 909.20 \\
\hline GW-680 & 0 & H & 0.00 & 57935 & 27224 & 115.00 & 884.80 \\
\hline GW-680 & 1 & H & 6.00 & 57905 & 27224 & 44.00 & 955.80 \\
\hline GW-681 & 0 & H & 0.00 & 58052 & 26870 & 100.00 & 968.50 \\
\hline GW-681 & 0 & H & 0.00 & 58052 & 26870 & 119.00 & 949.50 \\
\hline GW-681 & 0 & H & 0.00 & 58052 & 26870 & 185.00 & 883.50 \\
\hline$G W-681$ & 1 & H & 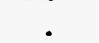 & 58052 & 26870 & 175.00 & 893.50 \\
\hline GW-681 & 1 & H & 12.00 & 58052 & 26870 & 71.00 & 997.50 \\
\hline GW-682 & 0 & H & 0.00 & 58209 & 27023 & 166.00 & 875.75 \\
\hline GW-682 & 1 & $H$ & 20.00 & 58209 & 27023 & 80.00 & 961.75 \\
\hline GW-683 & 1 & H & 1.00 & 41552 & 28282 & 31.00 & 938.45 \\
\hline GW-683 & 1 & H & 5.00 & 41552 & 28282 & 113.00 & 856.45 \\
\hline GW-683 & 1 & H & 9.00 & 41552 & 28282 & 149.00 & 820.45 \\
\hline GW-683 & 0 & H & 0.00 & 41552 & 28282 & 123.00 & 846.45 \\
\hline GW-684 & 1 & H & 1.00 & 41354 & 28525 & 31.00 & 864.53 \\
\hline GW-709 & 0 & H & 0.00 & 52372 & 25344 & 65.60 & 838.24 \\
\hline GW-709 & 0 & H & 0.00 & 52372 & 25344 & 74.50 & 829.34 \\
\hline GW-710 & 0 & $H$ & 0.00 & 36471 & 27645 & 58.00 & 850.03 \\
\hline GW-710 & 0 & H & 0.00 & 36471 & 27645 & 103.00 & 805.03 \\
\hline GW-710 & 0 & H & 0.00 & 36471 & 27645 & 168.00 & 740.03 \\
\hline GW-710 & 0 & H & 0.00 & 36471 & 27645 & 18530 & 722.73 \\
\hline GW.710 & 0 & H & 0.00 & 36471 & 27645 & 350.00 & 558.03 \\
\hline GW-710 & 0 & H & 0.00 & 36471 & 27645 & 479.70 & 428.33 \\
\hline GW-711 & 1 & $H$ & 3.00 & 36535 & 27873 & 17.50 & 884.46 \\
\hline GW-711 & 0 & H & 0.00 & $\mathbf{3 6 5 3 5}$ & 27873 & 246.00 & 655.96 \\
\hline
\end{tabular}




\begin{tabular}{|c|c|c|c|c|c|c|c|}
\hline $\begin{array}{l}\text { Well } \\
\text { Numbar }\end{array}$ & Type & Loc & $\begin{array}{l}\text { Size } \\
(f t)\end{array}$ & $\begin{array}{c}\text { Easting } \\
\text { (fi) }\end{array}$ & $\begin{array}{l}\text { Northing } \\
\text { (fi) }\end{array}$ & $\begin{array}{c}\text { Depth } \\
\text { Water (ft) }\end{array}$ & $\begin{array}{l}\text { Elevation } \\
\text { Water (fi) }\end{array}$ \\
\hline GW-711 & 0 & H & 0.00 & 36535 & 27873 & 65.00 & 836.96 \\
\hline GW-711 & 0 & $\mathrm{H}$ & 0.00 & 36535 & 27873 & 120.50 & 781.46 \\
\hline GW-711 & 0 & $H$ & 0.00 & 36535 & 27873 & 186.00 & 715.96 \\
\hline GW-711 & 0 & H & 0.00 & 36535 & 27873 & 284.00 & 617.96 \\
\hline GW-711 & 0 & $\mathbf{H}$ & 0.00 & 36535 & 27873 & 299.00 & 602.96 \\
\hline GW-711 & 0 & $H$ & 0.00 & 36535 & 27873 & 316.00 & 585.96 \\
\hline GW-711 & 0 & $\mathbf{H}$ & 0.00 & 36535 & 27873 & 412.00 & 489.96 \\
\hline GW-712 & 0 & v & 0.00 & 36507 & 28233 & 114.00 & 759.61 \\
\hline GW-712 & 1 & V & 1.00 & 36507 & 28233 & 13.00 & 860.61 \\
\hline GW-712 & 1 & V & 1.00 & 36507 & 28233 & 15.50 & 858.11 \\
\hline GW-712 & 1 & V & 2.00 & 36507 & 28233 & 20.00 & 853.61 \\
\hline GW-712 & 1 & V & 2.00 & 36507 & 28233 & 22.50 & 851.11 \\
\hline GW-712 & 1 & $v$ & 0.50 & 36507 & 28233 & 28.00 & 845.61 \\
\hline GW-712 & 1 & v & 1.00 & 36507 & 28233 & 47.00 & 826.61 \\
\hline GW-712 & 1 & V & 1.00 & 36507 & 28233 & 62.00 & 811.61 \\
\hline GW-712 & o & V & 0.00 & 36507 & 28233 & 38.00 & 835.61 \\
\hline GW-712 & 0 & V & 0.00 & 36507 & 28233 & 85.00 & 788.61 \\
\hline GW-713 & 1 & $V$ & 2.70 & 36434 & 28236 & 31.80 & 846.03 \\
\hline GW-713 & 1 & v & 5.00 & 36434 & 28236 & 35.80 & 842.03 \\
\hline GW-713 & 1 & $v$ & 4.70 & 36434 & 28236 & 43.80 & 834.03 \\
\hline GW-713 & 1 & $V$ & 7.00 & 36434 & 28236 & 54.80 & 823.03 \\
\hline GW-713 & 1 & $v$ & 2.00 & 36434 & 28236 & 66.80 & 811.03 \\
\hline GW-723 & 0 & $H$ & 0.00 & 49089 & 29006 & 60.00 & 959.31 \\
\hline GW-723 & $\mathbf{0}$ & $\mathrm{H}$ & 0.00 & 49089 & 29006 & 94.50 & 924.81 \\
\hline GW-723 & 0 & $\mathbf{H}$ & 0.00 & 49089 & 29006 & 119.70 & 899.61 \\
\hline GW-723 & 0 & $H$ & 0.00 & 49089 & 29006 & 127.00 & 89231 \\
\hline GW-731 & 1 & $\mathbf{R}$ & 2020 & 63853 & 27464 & 109.20 & 936.55 \\
\hline GW-731 & 1 & $\mathbf{R}$ & 5.00 & 63863 & 27464 & 140.00 & 905.75 \\
\hline GW-731 & 1 & $\mathbf{R}$ & 2.60 & 63863 & 27464 & 164.50 & 88125 \\
\hline GW-732 & 1 & $\mathbf{R}$ & 3.00 & 64268 & 27717 & 93.00 & 967.65 \\
\hline GW-732 & $\mathbf{0}$ & $\mathbf{R}$ & 0.00 & 64268 & 27717 & 181.60 & 879.05 \\
\hline GW-733 & 1 & H & 2.00 & 65057 & 28447 & 45.10 & 910.59 \\
\hline GW-739 & 0 & H & 0.00 & 49126 & 29010 & 118.20 & 902.46 \\
\hline GW-739 & o & H & 0.00 & 49126 & 29010 & 9720 & 923.46 \\
\hline GW-740 & 0 & $H$ & 0.00 & 49055 & 29027 & 71.00 & 945.95 \\
\hline GW-740 & 0 & $\mathbf{H}$ & 0.00 & 49055 & 29027 & 98.60 & 918.35 \\
\hline GW-742 & 1 & $\mathbf{R}$ & 3.00 & 58908 & 28038 & 90.00 & 1004.83 \\
\hline GW-742 & 1 & A & 1.00 & 58908 & 28038 & 180.00 & 917.83 \\
\hline GW-742 & 0 & $\mathbf{R}$ & 0.00 & 58908 & 28038 & 189.50 & 908.33 \\
\hline GW-742 & 0 & $\mathbf{R}$ & 0.00 & 58008 & 28038 & 265.00 & 832.83 \\
\hline GW-742 & 0 & $\mathbf{R}$ & 0.00 & 58908 & 28038 & 289.50 & 80833 \\
\hline GW-742 & 0 & $\mathbf{R}$ & 0.00 & 58908 & 28038 & 307.00 & 790.83 \\
\hline GW-742 & 0 & $\mathbf{R}$ & 0.00 & 58908 & 28038 & 160.00 & 937.83 \\
\hline GW-743 & 1 & $\mathbf{R}$ & 1.00 & 58908 & 28056 & 63.50 & 103522 \\
\hline GW-743 & 1 & $\mathbf{R}$ & 2.50 & 58908 & 28056 & 75.50 & 1023.22 \\
\hline GW-743 & 1 & $\mathbf{R}$ & 0.50 & 58908 & 28056 & 88.00 & 1010.72 \\
\hline GW-743 & 0 & $\mathbf{R}$ & 0.00 & 58908 & 28056 & 151.50 & 947.22 \\
\hline GW-520 & 1 & H & 19.00 & 46725 & 28885 & 44.00 & 941.18 \\
\hline GW-601 & 1 & $\mathrm{H}$ & sin & $47 \approx 29$ & 28903 & 23.50 & 975.59 \\
\hline GW-602 & 1 & $H$ & 2.00 & 47430 & 28640 & 65.00 & 1010.06 \\
\hline MIN & & & 0.00 & 36434 & 24226 & 5.00 & 428.33 \\
\hline MAX & & & 22.40 & 65057 & 29027 & 479.70 & 1098.06 \\
\hline AVE & & & 1.56 & 55372 & 27752 & 117.41 & 925.88 \\
\hline STDEV & & & 3.89 & 8195.12 & 990.01 & 74.71 & 107.66 \\
\hline $\mathbf{N}$ & 0 & 0 & 35.00 & 0.00 & 0.00 & 0.00 & 0.00 \\
\hline$T \cdot N$ & 290 & 290 & 255 & 290 & 290 & 290 & 290 \\
\hline
\end{tabular}




\begin{tabular}{|c|c|c|c|c|c|c|c|}
\hline $\begin{array}{l}\text { Well } \\
\text { Number }\end{array}$ & Type & Loc & $\begin{array}{c}\text { Size } \\
\text { (ft) }\end{array}$ & $\begin{array}{l}\text { Easting } \\
\text { (ft) }\end{array}$ & $\begin{array}{l}\text { Northing } \\
\text { (fi) }\end{array}$ & $\begin{array}{c}\text { Depth } \\
\text { Water (ft) }\end{array}$ & $\begin{array}{l}\text { Elevalion } \\
\text { Water }(\mathrm{ft})\end{array}$ \\
\hline \multicolumn{8}{|c|}{ Maynardville LImestone } \\
\hline 005-L & 1 & v & 4.50 & 57000 & 29500 & 1420 & 928.70 \\
\hline 005-L & 1 & v & & 57000 & 29500 & 29.00 & 913.90 \\
\hline 008-L & 1 & v & 6.00 & 56500 & 29500 & 13.70 & 933.60 \\
\hline 008-L & 1 & v & 7.00 & 56500 & 29500 & 24.70 & 922.60 \\
\hline 008-L & 1 & v & 10.30 & 56500 & 29500 & 32.00 & 915.30 \\
\hline $011-L$ & 1 & v & 0.40 & 56000 & 29500 & 37.80 & 912.80 \\
\hline $017-L$ & 1 & v & 0.30 & 55000 & 29500 & 1220 & 953.90 \\
\hline $017-L$ & 1 & v & 0.50 & 55000 & 29500 & 23.80 & 94230 \\
\hline 032-L & 1 & v & 0.60 & 55250 & 29750 & 10.00 & 952.50 \\
\hline 032-L & 1 & v & 0.50 & 55250 & 29750 & 17.20 & 945.30 \\
\hline $55-8 A\left({ }^{*+1}\right)$ & 1 & v & 3.00 & 55934 & 29755 & 19.00 & 941.00 \\
\hline 55-8B ("*) & 1 & v & 220 & 55902 & 29739 & 19.30 & 940.70 \\
\hline 55.88 (") & 1 & v & 10.50 & 55902 & 29739 & 27.50 & 932.50 \\
\hline $56-58$ & 1 & v & . & 56828 & 29382 & 35.10 & 930.77 \\
\hline $56-5 \mathrm{C}$ & 1 & v & 3.00 & 56819 & 29375 & 34.00 & 932.34 \\
\hline $56-5 C$ & 1 & $v$ & 1.50 & 56819 & 29375 & 42.00 & 92434 \\
\hline $60-1 C$ & 1 & v & 2.50 & 60210 & 29227 & 31.00 & 898.40 \\
\hline $60-1 C$ & 1 & $v$ & 0.70 & 60210 & 29227 & 42.50 & 886.90 \\
\hline $60-1 C$ & 1 & $v$ & 2.00 & 60210 & 29227 & 44.50 & 884.90 \\
\hline $60-1 C$ & 0 & $v$ & 0.00 & 60210 & 29227 & 21.20 & 90820 \\
\hline $60.1 \mathrm{C}$ & 0 & v & 0.00 & 60210 & 29227 & 30.00 & 899.40 \\
\hline $60-1 C$ & 0 & v & 0.00 & 60210 & 29227 & 39.50 & 889.90 \\
\hline BC-49 & 1 & H & 0.90 & 19743 & 28056 & 53.40 & 80520 \\
\hline$B C-50$ & 1 & $v$ & 0.50 & 19793 & 28270 & 41.40 & 787.60 \\
\hline BC. 57 & 1 & $v$ & 0.10 & 18711 & 28416 & 4730 & 770.20 \\
\hline BC-57 & 1 & $v$ & 1.80 & 18711 & 28416 & 49.80 & 767.70 \\
\hline GW-114 & 1 & $v$ & 15.00 & 28100 & 28575 & 23.50 & 800.86 \\
\hline GW-117 & 0 & $v$ & 0.00 & 42918 & 29183 & 30.00 & 881.19 \\
\hline GW-118 & 0 & $v$ & 0.00 & 43404 & 29147 & 45.00 & 864.37 \\
\hline GW-119 & 0 & v & 0.00 & 44098 & 29254 & 30.00 & 888.12 \\
\hline GW-122 & 0 & $v$ & 0.00 & 51807 & 29741 & 45.00 & 959.15 \\
\hline GW-123 & 0 & $v$ & 0.00 & 51794 & 29742 & 47.00 & 957.43 \\
\hline GW-124 & 0 & $v$ & 0.00 & 52223 & 29656 & 34.00 & 969.51 \\
\hline GW-125 & 1 & v & 2.00 & 522008 & 29646 & 40.50 & 963.48 \\
\hline GW-125 & 0 & $v$ & 0.00 & 52208 & 29646 & 50.00 & 953.98 \\
\hline$G W-149$ & 0 & $v$ & 0.00 & 63824 & 29201 & 4.00 & 900.76 \\
\hline GW-149 & o & v & 0.00 & $\varpi 824$ & 29201 & 25.00 & 879.76 \\
\hline GW-151 & 0 & $v$ & 0.00 & 64232 & 28958 & 26.00 & 887.06 \\
\hline GW-153 & 0 & $v$ & 0.00 & œ728 & 28613 & 29.00 & 889.53 \\
\hline GW-154 & 0 & $v$ & 0.00 & 63346 & 28987 & 5.00 & 903.60 \\
\hline GW-172 & 1 & H & 3.00 & 69579 & 28359 & 16.00 & 907.07 \\
\hline GW-172 & 0 & $H$ & 0.00 & 69579 & 28359 & 117.00 & 806.07 \\
\hline GW-172 & 0 & H & 0.00 & 69579 & 28359 & 130.00 & 793.07 \\
\hline GW-213 & 1 & v & 3.00 & 9091 & 27644 & 30.00 & 721.03 \\
\hline GW-213 & 1 & v & 4.03 & 9091 & 27644 & 104.00 & 647.03 \\
\hline GW-213 & 1 & v & 4.00 & 9091 & 27644 & 111.00 & 640.03 \\
\hline GW-214 & 1 & $v$ & & 9091 & 27701 & 232.00 & 518.78 \\
\hline GW-214 & 0 & $v$ & 0.00 & 9091 & 27701 & 112.00 & $\$ 38.78$ \\
\hline GW-214 & 0 & $v$ & 0.00 & 9091 & 27701 & 138.00 & 612.78 \\
\hline GW-214 & 0 & $v$ & 0.00 & 9091 & 27701 & 156.00 & 594.78 \\
\hline GW-214 & 0 & $v$ & 0.00 & 9091 & 27701 & 286.00 & 464.78 \\
\hline GW-218 & 1 & v & 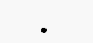 & 58878 & 29136 & 9.00 & 923.77 \\
\hline GW-218 & 1 & v & $\cdot$ & 58878 & 29136 & 22.50 & 910.27 \\
\hline GW-218 & 0 & $v$ & 0.00 & 58878 & 29136 & 10.50 & 922.27 \\
\hline GW-220 & 0 & v & 0.00 & 64225 & 28949 & 11.00 & 901.74 \\
\hline GW-2222 & 1 & v & & 6324 & 28954 & 19.00 & 889.82 \\
\hline GW-223 & 1 & $v$ & 2.00 & 63311 & 28938 & 57.00 & 851.97 \\
\hline GW-223 & 0 & v & 0.00 & $\approx 311$ & 28988 & 17.00 & 891.97 \\
\hline GW-223 & 0 & v & 0.00 & $\approx 311$ & 28938 & 27.50 & 881.47 \\
\hline GW-223 & 0 & $v$ & 0.00 & 63311 & 28938 & 34.00 & 874.97 \\
\hline GW-223 & 0 & v & 0.00 & 63311 & 28938 & 66.00 & 842.97 \\
\hline
\end{tabular}




\begin{tabular}{|c|c|c|c|c|c|c|c|}
\hline $\begin{array}{l}\text { Well } \\
\text { Number }\end{array}$ & Type & Loc & $\begin{array}{c}\text { Size } \\
\text { (ti) }\end{array}$ & $\begin{array}{c}\text { Easting } \\
\text { (t) }\end{array}$ & $\begin{array}{l}\text { Northing } \\
\text { (fi) }\end{array}$ & $\begin{array}{c}\text { Depth } \\
\text { Water (fi) }\end{array}$ & $\begin{array}{l}\text { Elevation } \\
\text { Water (ft) }\end{array}$ \\
\hline GW-223 & 0 & v & 0.00 & 63311 & 28938 & 68.50 & 840.47 \\
\hline GW-225 & 0 & v & 0.00 & 47461 & 29155 & 30.00 & 910.21 \\
\hline GW-226 & 0 & v & 0.00 & 47473 & 29156 & 24.00 & 916.56 \\
\hline GW-226 & 0 & v & 0.00 & 47473 & 29156 & 30.00 & 910.56 \\
\hline GW-227 & 1 & v & 0.50 & 47802 & 29172 & 25.50 & 918.41 \\
\hline GW-227 & 1 & v & 0.50 & 47802 & 29172 & 34.50 & 909.41 \\
\hline GW-227 & 1 & v & 0.50 & 47802 & 29172 & 37.00 & $906.9 t$ \\
\hline GW-228 & 1 & $v$ & 0.50 & 47791 & 29171 & 36.00 & 907.85 \\
\hline GW-228 & 1 & v & 1.00 & 47791 & 29171 & 40.00 & 903.85 \\
\hline GW-228 & 1 & v & 10.00 & 47791 & 29171 & 90.00 & 853.85 \\
\hline GW-229 & 1 & v & 12.00 & 47017 & 29256 & 43.00 & 902.71 \\
\hline GW-229 & 0 & $v$ & 0.00 & 47017 & 29256 & 25.00 & 920.71 \\
\hline GW-229 & 0 & $v$ & 0.00 & 47017 & 29256 & $\mathbf{3 0 . 0 0}$ & 915.71 \\
\hline GW-230 & 1 & H & 8.00 & 69617 & 28389 & 30.00 & 889.81 \\
\hline GW-230 & 0 & H & 0.00 & 69617 & 28389 & 146.00 & 773.81 \\
\hline GW-230 & 0 & H & 0.00 & 69617 & 28389 & 403.00 & 516.81 \\
\hline GW-232 & 0 & $H$ & 0.00 & 66863 & 28546 & 200.00 & 729.52 \\
\hline GW-235 & 1 & H & 7.00 & 69712 & 28416 & 7.00 & 912.99 \\
\hline GW-235 & 1 & $\mathrm{H}$ & 3.00 & 69712 & 28416 & 24.00 & 895.99 \\
\hline GW-235 & 1 & $H$ & 8.00 & 69712 & 28416 & 34.00 & 885.99 \\
\hline GW-235 & 1 & H & 2.00 & 69712 & 28416 & 50.00 & 869.99 \\
\hline GW-238 & 1 & $v$ & 3.00 & 9088 & 27737 & 30.00 & 720.97 \\
\hline GW-238 & 1 & $v$ & 2.00 & 9088 & 27737 & 35.00 & 715.97 \\
\hline GW-240 & 0 & H & 0.00 & 63726 & 28604 & 29.00 & 890.50 \\
\hline GW-251 & 0 & $v$ & 0.00 & 53843 & 29467 & 71.00 & $\$ 30.60$ \\
\hline GW-278 & 0 & $v$ & 0.00 & 53593 & 29649 & 16.00 & 978.66 \\
\hline GW-279 & 0 & $v$ & 0.00 & 53501 & 29639 & 27.00 & 968330 \\
\hline GW-279 & 0 & $v$ & 0.00 & 53591 & 29639 & 71.00 & 924.30 \\
\hline GW-280 & 1 & $v$ & 1.00 & 53589 & 29630 & 35.00 & 960.42 \\
\hline GW-280 & 1 & v & 1.00 & 53589 & 29030 & 38.00 & 957.42 \\
\hline GW-280 & 1 & v & 1.00 & 53589 & 29630 & 136.00 & 859.42 \\
\hline GW-280 & 0 & $v$ & 0.00 & 53589 & 29630 & 22.00 & 973.42 \\
\hline GW-280 & 0 & $v$ & 0.00 & 53589 & 29030 & 27.00 & 968.42 \\
\hline GW-306 & 0 & v & 0.00 & 49655 & 29346 & 48.00 & 941.44 \\
\hline GW-309 & 0 & $v$ & 0.00 & 50176 & 29530 & 27.00 & 958.77 \\
\hline GW-309 & 0 & v & 0.00 & 50176 & 29530 & 30.00 & 955.77 \\
\hline GW-309 & 0 & v & 0.00 & 50176 & 29530 & 32.50 & 953.27 \\
\hline GW-309 & 0 & v & 0.00 & 50176 & 29530 & 35.70 & 950.07 \\
\hline GW-313 & 1 & H & 3.00 & 52016 & 29351 & 103.00 & 947.37 \\
\hline GW-313 & 0 & H & 0.00 & 52016 & 29351 & 34.00 & 1016.37 \\
\hline GW-313 & 0 & $H$ & 0.00 & 52016 & 29351 & 69.00 & 981.37 \\
\hline GW-313 & 0 & H & 0.00 & 52016 & 29951 & 84.00 & 966.37 \\
\hline GW-313 & 0 & H & 0.00 & 52016 & 29351 & 91.00 & 959.37 \\
\hline GW-313 & 0 & $H$ & 0.00 & 52016 & 29351 & 101.00 & 949.37 \\
\hline GW-314 & 1 & $H$ & . & 52125 & 29419 & 30.00 & 101720 \\
\hline GW-314 & 1 & $H$ & & 52125 & 29419 & 48.00 & 999.20 \\
\hline GW-314 & 0 & H & 0.00 & 52125 & 29419 & 108.00 & 939.20 \\
\hline GW-315 & 1 & H & ${ }^{\circ}$ & 52268 & 29455 & 62.00 & 982.84 \\
\hline GW-315 & 1 & $H$ & & 52268 & 29455 & 68.50 & 976.34 \\
\hline GW-315 & 0 & $\mathrm{H}$ & 0.00 & 52268 & 29455 & 61.50 & 98334 \\
\hline GW-315 & 0 & H & 0.00 & 52268 & 29455 & 86.50 & 95834 \\
\hline GW-315 & 0 & H & 0.00 & 52268 & 29455 & 94.50 & 95034 \\
\hline GW-348 & 0 & H & 0.00 & $507 \circledast 3$ & 29294 & 76.40 & 921.60 \\
\hline GW-349 & 0 & v & 0.00 & 53588 & 29766 & 13.00 & 977.98 \\
\hline GW-350 & 1 & v & 2.00 & 53595 & 29764 & 22.00 & 969.00 \\
\hline GW-350 & 1 & v & & 53595 & 29764 & 35.00 & 956.00 \\
\hline GW-350 & 0 & v & 0.00 & 53595 & 29764 & 27.00 & 964.00 \\
\hline GW-350 & 0 & v & 0.00 & 53595 & 29764 & 40.00 & 951.00 \\
\hline GW-365 & 0 & v & 0.00 & 46490 & 29150 & 78.00 & 855.03 \\
\hline GW-365 & 0 & v & 0.00 & 46490 & 29150 & 142.00 & 791.03 \\
\hline GW-375 & 1 & $v$ & & 44136 & 29278 & 15.40 & 904.08 \\
\hline GW-375 & 1 & v & . & 44136 & 29278 & 17.50 & 901.98 \\
\hline
\end{tabular}




\begin{tabular}{|c|c|c|c|c|c|c|c|}
\hline $\begin{array}{l}\text { Well } \\
\text { Number }\end{array}$ & Type & Loc & $\begin{array}{l}\text { Size } \\
\text { (fi) }\end{array}$ & $\begin{array}{l}\text { Easting } \\
\text { (t) }\end{array}$ & $\begin{array}{l}\text { Northing } \\
\text { (fi) }\end{array}$ & $\begin{array}{c}\text { Depth } \\
\text { Water (ft) }\end{array}$ & $\begin{array}{l}\text { Elevation } \\
\text { Water (ft) }\end{array}$ \\
\hline GW-375 & 1 & v & • & 44136 & 29278 & 19.80 & 899.68 \\
\hline GW-375 & 1 & v & • & 44136 & 29278 & 30.50 & 888.98 \\
\hline GW-375 & 1 & v & . & 44136 & 29278 & 36.00 & 883.48 \\
\hline GW-375 & 0 & v & 0.00 & 44136 & 29278 & 29.00 & 890.48 \\
\hline GW-375 & 0 & v & 0.00 & 44136 & 29278 & 129.00 & 790.48 \\
\hline GW-375 & 0 & v & 0.00 & 44136 & 29278 & 160.70 & 758.78 \\
\hline GW-381 & 1 & v & . & 62947 & 28715 & 16.30 & 897.10 \\
\hline GW-381 & 1 & v & . & 62947 & 28715 & 17.00 & 896.40 \\
\hline GW-381 & 1 & v & . & 62947 & 28715 & 19.60 & 893.80 \\
\hline GW-381 & 1 & v & . & 62947 & 28715 & 24.50 & 888.90 \\
\hline GW-382 & 1 & v & . & 62956 & 28716 & 16.00 & 897.16 \\
\hline GW-382 & 0 & v & 0.00 & 62956 & 28716 & 163.00 & 750.16 \\
\hline$G W-443$ & 1 & v & $\cdot$ & 31881 & 28714 & 42.00 & 785.75 \\
\hline GW-600 & 1 & H & 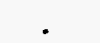 & 64803 & 28430 & 39.00 & 920.41 \\
\hline GW-603 & 1 & H & 2.00 & 64803 & 28430 & 45.00 & 914.41 \\
\hline GW-603 & 1 & H & 3.40 & 64803 & 28430 & 55.00 & 904.41 \\
\hline GW-603 & 0 & H & 0.00 & 64803 & 28430 & 67.00 & 892.41 \\
\hline GW-604 & 1 & H & 4.00 & 64837 & 28437 & 35.00 & 924.53 \\
\hline GW-604 & 1 & H & 4.00 & 64837 & 28437 & 43.00 & 916.53 \\
\hline GW-604 & 1 & H & 2.00 & 64837 & 28437 & 52.50 & 907.03 \\
\hline GW-604 & 0 & H & 0.00 & 64837 & 28437 & 86.00 & 873.53 \\
\hline GW-604 & o & H & 0.00 & 64837 & 28437 & 104.50 & 855.03 \\
\hline GW-605 & o & v & 0.00 & 62002 & 28707 & 33.00 & 883.97 \\
\hline GW-606 & 0 & v & 0.00 & 61951 & 28708 & 8.00 & 908.98 \\
\hline GW-606 & o & $v$ & 0.00 & 61951 & 28708 & 24.00 & 892.98 \\
\hline GW-606 & 1 & v & 3.00 & 61951 & 28708 & 58.00 & 858.98 \\
\hline GW-606 & 1 & v & 1.08 & 61951 & 28708 & 67.00 & 849.98 \\
\hline$G W-616$ & D & v & 0.00 & 51907 & 29724 & 69.00 & 940.81 \\
\hline GW-618 & 0 & v & 0.00 & 54738 & 29798 & 32.00 & 950.64 \\
\hline GW-620 & o & v & 0.00 & 52895 & 29565 & 5020 & 962.64 \\
\hline GW-620 & 0 & v & 0.00 & 52895 & 29565 & 68.00 & 944.84 \\
\hline GW-621 & 1 & $v$ & 16.00 & 45033 & 29003 & 27.00 & 896.07 \\
\hline GW-645 & 1 & H & 4.50 & 46649 & 28837 & 19.00 & 984.50 \\
\hline GW-645 & 1 & H & 1.00 & 46649 & 28837 & 27.00 & 976.50 \\
\hline GW-645 & 1 & H & 4.00 & 46649 & 28837 & 41.00 & 962.50 \\
\hline$G W \cdot 645$ & 1 & H & 2.00 & 46649 & 28837 & 58.00 & 945.50 \\
\hline GW-645 & 0 & H & 0.00 & 46649 & 28837 & 73.50 & $\$ 30.00$ \\
\hline GW-645 & 0 & H & 0.00 & 46649 & 28837 & 76.00 & 927.50 \\
\hline GW-646 & 0 & R & 0.00 & 47580 & 28873 & 68.00 & $\$ 34.01$ \\
\hline GW-647A & 0 & H & 0.00 & . & . & 13.00 & 1017.14 \\
\hline GW-648 & 1 & $H$ & 2.00 & 49888 & 29088 & 51.00 & 975.48 \\
\hline GW.648 & 1 & H & 2.50 & 49888 & 29088 & 57.50 & 968.98 \\
\hline GW-648 & 1 & H & 1.50 & 49888 & 29088 & 6250 & 963.98 \\
\hline GW-648 & 0 & H & 0.00 & 49888 & 29088 & 70.50 & 955.98 \\
\hline GW-652 & 0 & v & 0.00 & 42452 & 29029 & 22.50 & 875.48 \\
\hline GW-684 & 1 & $H$ & 1.00 & 41354 & 28525 & 72.00 & 823.53 \\
\hline GW-684 & 1 & H & 2.00 & 41354 & 28525 & 122.00 & 773.53 \\
\hline GW-684 & 0 & H & 0.00 & 41354 & 28525 & 110.00 & 785.53 \\
\hline GW-685 & 1 & v & 1.30 & 41448 & 28667 & 13.70 & 875.58 \\
\hline GW-685 & 1 & v & 2.00 & 41448 & 28667 & 37.00 & 85228 \\
\hline GW-685 & 0 & v & 0.00 & 41448 & 28667 & 64.00 & 825.28 \\
\hline GW-685 & 0 & v & 0.00 & 41448 & 28667 & 110.00 & 779.28 \\
\hline GW-688 & 0 & v & 0.00 & 55604 & 29688 & 54.00 & 913.46 \\
\hline GW-690 & 0 & v & 0.00 & 55990 & 29787 & 53.00 & 914.71 \\
\hline GW-692 & 0 & v & 0.00 & 56001 & 29653 & 52.00 & 912.55 \\
\hline GW-692 & 1 & v & & 56001 & 29653 & 52.00 & 961.55 \\
\hline GW-694 & 0 & H & 0.00 & 44893 & 28845 & 23.00 & 915.58 \\
\hline GW-694 & $\mathbf{0}$ & $H$ & 0.00 & 44893 & 28845 & 32.00 & $\mathbf{9 0 6 . 5 8}$ \\
\hline GW-694 & 0 & $H$ & 0.00 & 44803 & 28845 & 70.00 & 868.58 \\
\hline GW-694 & 0 & H & 0.00 & 44693 & 28845 & 94.00 & 844.58 \\
\hline GW-694 & 0 & H & 0.00 & 44893 & 28845 & 194.50 & 744.08 \\
\hline & 0 & H & $0 \mathrm{~m}$ & & & 202.00 & 736.58 \\
\hline
\end{tabular}




\begin{tabular}{|c|c|c|c|c|c|c|c|}
\hline $\begin{array}{l}\text { Well } \\
\text { Number }\end{array}$ & Type & Loc & $\begin{array}{l}\text { Size } \\
\text { (ft) }\end{array}$ & $\begin{array}{l}\text { Easting } \\
\text { (fi) }\end{array}$ & $\begin{array}{l}\text { Northing } \\
\text { (ft) }\end{array}$ & $\begin{array}{c}\text { Depth } \\
\text { Water (ft) }\end{array}$ & $\begin{array}{l}\text { Elevation } \\
\text { Water (fi) }\end{array}$ \\
\hline GW-694 & o & $H$ & 0.00 & 44893 & 28845 & 23.00 & 915.58 \\
\hline GW-694 & 0 & $H$ & 0.00 & 44893 & 28845 & 32.00 & 906.58 \\
\hline GW-694 & 0 & H & 0.00 & 44893 & 28845 & 70.00 & 868.58 \\
\hline GW-694 & 0 & H & 0.00 & 44893 & 28845 & 94.00 & 844.58 \\
\hline GW-694 & 0 & $H$ & 0.00 & 44893 & 28845 & 194.50 & 744.08 \\
\hline GW-696 & 0 & v & 0.00 & 56810 & 29277 & 202.00 & 767.78 \\
\hline GW-697 & 0 & $v$ & 0.00 & 56806 & 29277 & 10.00 & 959.81 \\
\hline GW-698 & 0 & $v$ & 0.00 & 56804 & 29277 & 75.00 & 895.09 \\
\hline GW-698 & 1 & v & & 56804 & 29277 & 42.00 & 928.09 \\
\hline GW-699 & 0 & v & 0.00 & 56844 & 29168 & 9.00 & 95739 \\
\hline GW-700 & 0 & $v$ & 0.00 & 56828 & 29452 & 30.50 & 92728 \\
\hline GW-703 & 0 & $H$ & 0.00 & 44981 & 28806 & 47.50 & 90430 \\
\hline GW-703 & 0 & H & 0.00 & 44981 & 28806 & 57.50 & 894,30 \\
\hline GW-703 & 0 & $H$ & 0.00 & 44981 & 28806 & 160.00 & 791.80 \\
\hline GW-704 & 0 & H & 0.00 & 44935 & 28845 & 50.00 & 891.99 \\
\hline GW-704 & D & $H$ & 0.00 & 44965 & 28845 & 110.00 & 831.99 \\
\hline GW-704 & 0 & H & 0.00 & 44935 & 28845 & 255.00 & 686.99 \\
\hline GW-705 & o & $v$ & 0.00 & 44916 & 28945 & 10.00 & 914.96 \\
\hline GW-705 & 0 & $v$ & 0.00 & 44916 & 28945 & 79.00 & 845.96 \\
\hline GW-705 & 0 & $v$ & 0.00 & 44916 & 28945 & 120.00 & 804.96 \\
\hline GW-705 & 0 & $v$ & 0.00 & 44916 & 28945 & 180.00 & 744.96 \\
\hline GW-706 & 0 & $v$ & 0.00 & 44944 & 28946 & 116.00 & 809.78 \\
\hline GW-706 & o & $v$ & 0.00 & 44944 & 28946 & 133.00 & 792.78 \\
\hline GW-706 & 0 & $v$ & 0.00 & 44944 & 28946 & 171.50 & 754.28 \\
\hline GW-706 & o & $v$ & 0.00 & 44944 & 28946 & 175.50 & 750.28 \\
\hline GW-711 & o & $H$ & 0.00 & 36535 & 27873 & 650.00 & 251.96 \\
\hline GW-712 & o & $v$ & 0.00 & 36507 & 28233 & 271.00 & 602.61 \\
\hline GW-712 & 0 & $v$ & 0.00 & 36507 & 28233 & 274.00 & 599.61 \\
\hline GW-712 & 0 & v & 0.00 & 36507 & 28233 & 155.20 & 718.41 \\
\hline GW-712 & 0 & $v$ & 0.00 & 36507 & 28233 & 180.20 & 693.41 \\
\hline GW-712 & 0 & $v$ & 0.00 & 36507 & 28233 & 311.00 & 562.61 \\
\hline GW-712 & 0 & $v$ & 0.00 & 36507 & 28233 & 341.20 & 532.41 \\
\hline GW-712 & 0 & $v$ & 0.00 & 36507 & 28233 & 403.50 & 470.11 \\
\hline GW-712 & 0 & $v$ & 0.00 & 36507 & 28233 & 408.50 & 465.11 \\
\hline GW-712 & 0 & $v$ & 0.00 & 36507 & 28233 & 430.50 & 443.11 \\
\hline GW-712 & 0 & $v$ & 0.00 & 36507 & 28233 & 438.50 & 435.11 \\
\hline GW-712 & 0 & $v$ & 0.00 & 36507 & 28233 & 447.50 & 426.11 \\
\hline GW-713 & 1 & $v$ & 1.50 & 36434 & 28236 & 163.00 & 714.83 \\
\hline GW-713 & 1 & $v$ & 1.00 & 36434 & 28236 & 218.80 & 659.03 \\
\hline GW-713 & 0 & $v$ & 0.00 & 36434 & 28236 & 199.80 & 678.03 \\
\hline GW-713 & 0 & $v$ & 0.00 & 36434 & 28236 & 144.00 & 733.83 \\
\hline GW-713 & 0 & $v$ & 0.00 & 36434 & 28236 & 224.00 & 653.83 \\
\hline GW-713 & 0 & $v$ & 0.00 & 36434 & 28236 & 272.80 & 605.03 \\
\hline GW-713 & 0 & $v$ & 0.00 & 36434 & 28236 & 308.00 & 569.83 \\
\hline GW-714 & 1 & $v$ & • & 36435 & 28422 & 42.00 & 830.30 \\
\hline GW-714 & 1 & $v$ & . & 36435 & 28422 & 58.00 & 81430 \\
\hline GW-714 & 1 & $v$ & . & 36435 & 28422 & 107.00 & 76530 \\
\hline GW-714 & o & $v$ & 0.00 & 36435 & 28422 & 33.00 & 839.30 \\
\hline GW-714 & 0 & $v$ & 0.00 & 36435 & 28422 & 133.00 & 739.30 \\
\hline GW-714 & o & $v$ & 0.00 & 36435 & 28422 & 34.50 & 837.80 \\
\hline GW-715 & 0 & $v$ & 0.00 & 36453 & 28425 & 43.60 & 828.57 \\
\hline GW-715 & 1 & $v$ & 1.00 & 36453 & 28425 & 37.60 & 834.57 \\
\hline GW-722 & 1 & $H$ & 7.00 & 64926 & 28532 & 58.50 & 892.54 \\
\hline GW-722 & 1 & $H$ & 3.10 & 64926 & 28532 & 100.00 & 851.04 \\
\hline GW-722 & 0 & H & 0.00 & 64926 & 28532 & 86.50 & 864.54 \\
\hline GW-722 & 0 & $H$ & 0.00 & 64986 & 28532 & 313.50 & 637.54 \\
\hline GW-722 & 0 & $\mathrm{H}$ & 0.00 & 64926 & 28532 & 334.00 & 617.04 \\
\hline GW-722 & o & H & 0.00 & 64926 & 28532 & 490.00 & 461.04 \\
\hline GW-723 & 0 & H & 0.00 & 49089 & 29006 & 140.70 & 878.61 \\
\hline GW-723 & 0 & $H$ & 0.00 & 49089 & 29006 & 150.00 & 86931 \\
\hline GW-723 & 0 & H & 0.00 & 49089 & 29006 & 162.00 & 85731 \\
\hline GW-723 & 0 & H & 0.00 & 49089 & 29006 & 183.00 & 83631 \\
\hline
\end{tabular}




\begin{tabular}{|c|c|c|c|c|c|c|c|}
\hline $\begin{array}{l}\text { Well } \\
\text { Number }\end{array}$ & Type & Loc & $\begin{array}{c}\text { Size } \\
\text { (fi) }\end{array}$ & $\begin{array}{c}\text { Easting } \\
\text { (ft) }\end{array}$ & $\begin{array}{l}\text { Northing } \\
\text { (fi) }\end{array}$ & $\begin{array}{c}\text { Depth } \\
\text { Water (ft) }\end{array}$ & $\begin{array}{l}\text { Elovation } \\
\text { Water (ti) }\end{array}$ \\
\hline GW-723 & 0 & $\mathrm{H}$ & 0.00 & 49089 & 29006 & 200.60 & 818.71 \\
\hline GW-723 & 0 & H & 0.00 & 49089 & 29006 & 235.00 & 784.31 \\
\hline GW-723 & 0 & H & 0.00 & 49089 & 29006 & 241.00 & 778.31 \\
\hline GW-723 & 0 & H & 0.00 & 49089 & 29006 & 298.60 & 720.71 \\
\hline GW-723 & 0 & H & 0.00 & 49089 & 29006 & 321.60 & 697.71 \\
\hline GW-723 & 0 & $\mathrm{H}$ & 0.00 & 49089 & 29006 & 431.50 & 587.81 \\
\hline GW-724 & 1 & $H$ & 2.00 & 48995 & 29198 & 36.50 & 940.12 \\
\hline GW-724 & 1 & $H$ & 1.00 & 48995 & 29198 & 54.00 & 922.62 \\
\hline GW-724 & $\mathbf{0}$ & H & 0.00 & 48995 & 29198 & 89.60 & 887.02 \\
\hline GW-724 & o & H & 0.00 & 48995 & 29198 & 138.60 & 838.02 \\
\hline GW-724 & 0 & H & 0.00 & 48995 & 29198 & 147.60 & 829.02 \\
\hline GW-724 & 0 & $H$ & 0.00 & 48995 & 29198 & 156.00 & 820.62 \\
\hline GW-724 & 0 & H & 0.00 & 48995 & 29198 & 165.00 & 811.62 \\
\hline GW-724 & 0 & H & 0.00 & 48995 & 29198 & 179.00 & 797.62 \\
\hline GW-724 & 0 & $H$ & 0.00 & 48995 & 29198 & 195.00 & 781.62 \\
\hline GW-724 & 0 & H & 0.00 & 48995 & 29198 & 201.60 & 775.02 \\
\hline GW-724 & 0 & $H$ & 0.00 & 48995 & 29198 & 231.60 & 745.02 \\
\hline GW-724 & 0 & $\mathrm{H}$ & 0.00 & 48995 & 29188 & 242.00 & 734.62 \\
\hline GW-724 & 0 & $H$ & 0.00 & 48995 & 29198 & 274.60 & 702.02 \\
\hline GW-724 & 0 & H & 0.00 & 48995 & 29198 & 299.00 & 677.62 \\
\hline GW-725 & 0 & v & 0.00 & 48989 & 29405 & 7.00 & 951.26 \\
\hline GW-725 & 0 & V & 0.00 & 48989 & 29405 & 78.50 & 879.76 \\
\hline GW-725 & 0 & v & 0.00 & 48989 & 29405 & 106.00 & 85226 \\
\hline GW-725 & 0 & V & 0.00 & 48989 & 29405 & 136.10 & 822.16 \\
\hline GW-725 & 0 & V & 0.00 & 48989 & 29405 & 104.50 & 853.76 \\
\hline GW-725 & 0 & V & 0.00 & 48989 & 29405 & 124.50 & 833.76 \\
\hline GW-725 & 0 & V & 0.00 & 48989 & 29405 & 142.50 & 815.76 \\
\hline GW-733 & 0 & $H$ & 0.00 & 65057 & 28447 & 152.00 & 8003.69 \\
\hline GW-733 & 0 & H & 0.00 & 65057 & 28447 & 178.20 & $\pi 7.49$ \\
\hline GW-733 & 0 & H & 0.00 & 65057 & 28447 & 21720 & 738.49 \\
\hline GW-733 & 0 & H & 0.00 & 65057 & 28447 & 100.10 & 855.59 \\
\hline GW-733 & 0 & H & 0.00 & 65057 & 28447 & 105.10 & 850.59 \\
\hline GW-733 & 0 & $H$ & 0.00 & 65057 & 28447 & 125.10 & 830.59 \\
\hline GW-733 & 0 & $\mathbf{H}$ & 0.00 & 65057 & 28447 & 168.10 & 787.59 \\
\hline GW-733 & 0 & H & 0.00 & 65057 & 28447 & 185.10 & 770.59 \\
\hline GW-733 & 0 & $H$ & 0.00 & 65057 & 28447 & 249.50 & $\cdot 706.19$ \\
\hline GW-734 & 1 & V & 3.90 & 64943 & 28682 & 41.50 & 895.92 \\
\hline GW-734 & 1 & v & 1.00 & 64943 & 28682 & 49.00 & 888.42 \\
\hline GW-734 & 1 & V & 1.40 & 64943 & 28682 & 54.00 & 883.42 \\
\hline GW-734 & 1 & V & 44.00 & 64943 & 28682 & 59.40 & 878.02 \\
\hline GW-736 & 0 & v & 0.00 & 48936 & 29381 & 4.00 & 953.55 \\
\hline GW-736 & 0 & v & 0.00 & 48936 & 29381 & 57.50 & 900.05 \\
\hline GW-736 & 0 & $v$ & 0.00 & 48936 & 29381 & 94.00 & 863.55 \\
\hline GW-737 & 1 & $V$ & 2.00 & 48800 & 29365 & 83.00 & 874.50 \\
\hline GW-737 & 0 & V & 0.00 & 48890 & 29365 & 55.60 & 901.90 \\
\hline GW-737 & 0 & V & 0.00 & 48890 & 29365 & 4.00 & 953.50 \\
\hline GW-738 & o & H & - & 49026 & 29150 & 84.00 & 89636 \\
\hline GW-738 & 0 & H & . & 49026 & 29150 & 89.00 & 891.36 \\
\hline GW-738 & 1 & H & 2.00 & 49026 & 29150 & 41.10 & 939.26 \\
\hline GW-738 & 1 & $\mathbf{H}$ & 1.40 & 49026 & 29150 & 50.10 & 930.26 \\
\hline GW-738 & 1 & $\mathbf{H}$ & 2.00 & 49026 & 29150 & 75.10 & 90526 \\
\hline GW-738 & 0 & $H$ & 0.00 & 49026 & 29150 & 33.50 & 946.86 \\
\hline GW-739 & $\mathbf{0}$ & H & 0.00 & 42126 & 29010 & 13620 & 884.46 \\
\hline GW-739 & o & H & 0.00 & 42126 & 29010 & 17220 & 848.46 \\
\hline GW-739 & 0 & H & 0.00 & 42126 & 29010 & 186.20 & 834.46 \\
\hline GW-739 & 0 & H & 0.00 & 42126 & 29010 & 224.50 & 796.16 \\
\hline GW-739 & 0 & H & 0.00 & 42126 & 29010 & 24320 & 777.46 \\
\hline GW-739 & 0 & $H$ & 0.00 & 42126 & 29010 & 24720 & 773.46 \\
\hline GW-739 & 0 & H & 0.00 & 42126 & 29010 & 127.50 & 893.16 \\
\hline GW-739 & 0 & H & 0.00 & 42126 & 29010 & 147.50 & 873.16 \\
\hline GW-739 & 0 & $H$ & 0.00 & 42126 & 29010 & 263.00 & 757.66 \\
\hline GW-739 & 0 & H & 0.00 & 42126 & 29010 & 274.00 & 746.66 \\
\hline
\end{tabular}




\begin{tabular}{|c|c|c|c|c|c|c|c|}
\hline $\begin{array}{l}\text { Well } \\
\text { Number }\end{array}$ & Type & LoC & $\begin{array}{l}\text { Size } \\
\text { (ft) }\end{array}$ & $\begin{array}{l}\text { Easting } \\
\text { (t) }\end{array}$ & $\begin{array}{l}\text { Northing } \\
\text { (fi) }\end{array}$ & $\begin{array}{c}\text { Depth } \\
\text { Water (fi) }\end{array}$ & $\begin{array}{l}\text { Elevation } \\
\text { Water (ft) }\end{array}$ \\
\hline GW-740 & 0 & $\mathbf{H}$ & 0.00 & 49055 & 29027 & 117.00 & 899.95 \\
\hline GW-740 & 0 & $H$ & 0.00 & 49055 & 29027 & 187.50 & 829.45 \\
\hline J-001 & 1 & v & 1.90 & 56995 & 29266 & 25.80 & 916.78 \\
\hline$J-001$ & 0 & v & 0.00 & 56995 & 29266 & 29.00 & 913.58 \\
\hline J-002 & 1 & v & 430 & 57007 & 29365 & 16.90 & 928.18 \\
\hline $\mathrm{J}-002$ & 1 & v & 1.90 & 57007 & 29365 & 28.30 & 916.78 \\
\hline$J-003$ & 1 & v & 130 & 57020 & 29464 & 4.50 & 940.17 \\
\hline $1-003$ & 1 & v & 2.30 & 57020 & 29464 & 7.00 & 937.67 \\
\hline $\mathrm{J}-003$ & 1 & v & 0.90 & 57020 & 29464 & 13.30 & 931.37 \\
\hline $\mathrm{J}-003$ & 1 & v & 2.10 & 57020 & 29464 & 15.30 & 929.37 \\
\hline $\mathrm{J}-004$ & 1 & v & 1.00 & 57033 & 29563 & 20.50 & 92733 \\
\hline J-005 & 1 & v & 1.20 & 57046 & 29662 & 20.00 & 932.25 \\
\hline$J-007$ & 1 & $v$ & 3.20 & 57192 & 29240 & 26.90 & 914.18 \\
\hline $\mathcal{J}-008$ & 1 & v & 8.00 & 57219 & 29438 & 14.00 & 931.42 \\
\hline J-008 & 1 & $v$ & 0.80 & 57219 & 29438 & 30.00 & 915.42 \\
\hline J.009 & 1 & $v$ & 0.80 & 57244 & 29637 & 20.00 & $\$ 36.96$ \\
\hline J.009 & 1 & v & 1.00 & 57244 & 29637 & 21.30 & 935.66 \\
\hline J-009 & 1 & $v$ & 2.00 & 57244 & 29637 & 25.70 & 93126 \\
\hline$J-009$ & 1 & v & 0.60 & 57244 & 29637 & 35.50 & 921.46 \\
\hline J-011 & 1 & $v$ & 9.10 & 57391 & 29214 & 8.70 & 929.97 \\
\hline J-011 & 1 & $v$ & 2.10 & 57391 & 29214 & 22.30 & 916.37 \\
\hline J-011 & 1 & v & 0.60 & 57391 & 29214 & 28.90 & 909.77 \\
\hline J.012 & 1 & $v$ & 6.20 & 57417 & 29413 & 20.80 & 92128 \\
\hline J-015 & 0 & $v$ & 0.00 & 57585 & 29168 & 4.00 & $\$ 35.47$ \\
\hline J-017 & 1 & v & 230 & 57639 & 29565 & 8.70 & 935.47 \\
\hline J-017 & 1 & v & 1.00 & $57 æ 39$ & 29565 & 18.00 & 926.17 \\
\hline $\mathfrak{J}-019$ & 1 & v & 0.50 & 56796 & 29292 & 15.50 & 928.75 \\
\hline J-019 & 1 & v & 1.00 & 56796 & 29292 & 20.00 & 924.25 \\
\hline J-020 & 1 & v & 3.70 & 56822 & 29490 & 25.00 & 922.75 \\
\hline $1-020$ & 0 & v & 0.00 & 56822 & 29490 & 7.00 & 940.75 \\
\hline$K-020$ & 1 & H & 1.60 & 62400 & 28600 & 1020 & 909.52 \\
\hline K-020 & $i$ & H & 0.20 & 62400 & 28600 & 21.80 & 897.92 \\
\hline K-020 & 1 & $H$ & 0.40 & 62400 & 28600 & 29.80 & 889.92 \\
\hline K1-015 & 1 & $v$ & 1920 & 64000 & 28850 & 17.70 & 894.68 \\
\hline K1-015 & 1 & v & 18.75 & 64000 & 28850 & 4025 & 872.13 \\
\hline K2-015 & 1 & $v$ & 18.60 & 64005 & 28850 & 18.70 & 893.80 \\
\hline GW-727 & 1 & . & . & 42540 & 28734 & 36.00 & 861.96 \\
\hline GW-727 & 1 & . & . & 42540 & 28734 & 40.00 & 857.96 \\
\hline GW-727 & 0 & . & . & 42540 & 28734 & 105.00 & 792.96 \\
\hline GW-727 & o & . & . & 42540 & 28734 & 35.00 & 862.96 \\
\hline GW-727 & 0 & . & . & 42540 & 28734 & 162.00 & 735.96 \\
\hline GW-727 & 0 & . & . & 42540 & 28734 & 204.50 & 693.46 \\
\hline GW-729 & 0 & . & . & 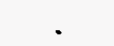 & $\cdot$ & 370.00 & $\cdot$ \\
\hline GW-729 & 0 & . & . & & . & 386.00 & \\
\hline GW-730 & 1 & . & . & 44608 & 28921 & 42.00 & 880.64 \\
\hline GW-730 & 1 & . & . & 44608 & 28921 & 73.00 & 849.64 \\
\hline GW-730 & 1 & . & . & 44608 & 28921 & 79.00 & 843.64 \\
\hline GW-730 & 0 & . & . & 44608 & 28921 & 108.00 & 814.64 \\
\hline GW-730 & 0 & . & . & 44608 & 28921 & 156.00 & 766.64 \\
\hline GW-730 & 0 & . & . & 44608 & 28921 & 188.00 & 734.64 \\
\hline GW-730 & 0 & . & . & 44608 & 28921 & 250.00 & 672.64 \\
\hline GW-730 & 0 & . & . & 44608 & 28921 & 264.00 & 658.64 \\
\hline GW-790 & 1 & . & . & $\cdot$ & - & 69.00 & - \\
\hline GW-790 & 1 & . & . & . & . & 199.30 & . \\
\hline GW-790 & 1 & . & . & . & . & 236.50 & . \\
\hline GW-790 & 0 & . & . & . & . & 114.00 & . \\
\hline GW-790 & 0 & . & . & . & . & 144.00 & . \\
\hline GW-790 & 0 & . & . & . & . & 182.00 & . \\
\hline GW-790 & 0 & . & . & . & . & 195.50 & . \\
\hline GW-790 & 0 & . & . & . & 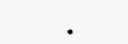 & 240.00 & 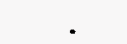 \\
\hline GW-790 & 1 & 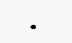 & 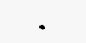 & . & & 201.00 & \\
\hline GW-193 & 1 & v & 3.00 & 59536 & 29344 & 9.00 & 922.11 \\
\hline
\end{tabular}




\begin{tabular}{|c|c|c|c|c|c|c|c|}
\hline $\begin{array}{l}\text { Well } \\
\text { Number }\end{array}$ & Туре & Loc & $\begin{array}{l}\text { Size } \\
(f t)\end{array}$ & $\begin{array}{l}\text { Easting } \\
\text { (ft) }\end{array}$ & $\begin{array}{l}\text { Northing } \\
\text { (ft) }\end{array}$ & $\begin{array}{c}\text { Depth } \\
\text { Wader (ii) }\end{array}$ & $\begin{array}{l}\text { Elevation } \\
\text { Water (ft) }\end{array}$ \\
\hline GW-204 & 0 & v & 0.00 & 57411 & 29956 & 5.60 & 949.87 \\
\hline GW-316 & 1 & $H$ & . & 52412 & 29336 & 39.50 & 100523 \\
\hline GW-316 & 0 & $\mathrm{H}$ & 0.00 & 52412 & 29336 & 69.00 & 975.73 \\
\hline GW-316 & 0 & $H$ & 0.00 & 52412 & 29336 & 71.00 & 973.73 \\
\hline GW-316 & 0 & $H$ & 0.00 & 52412 & 29336 & 76.00 & 968.73 \\
\hline GW-317 & 0 & $H$ & 0.00 & 52192 & 29285 & 110.00 & 950.80 \\
\hline GW-317 & 0 & $H$ & 0.00 & 52192 & 29285 & 122.00 & 938.80 \\
\hline GW-317 & 0 & $\mathrm{H}$ & 0.00 & 52192 & 29285 & 128.00 & 532.80 \\
\hline GW-366 & 1 & $H$ & . & 46708 & 28886 & 62.00 & 923.66 \\
\hline GW-367 & 0 & H & 0.00 & 46005 & 28884 & 64.00 & 922.21 \\
\hline GW-367 & 0 & $H$ & 0.00 & 46695 & 28884 & 68.00 & 918.21 \\
\hline GW-367 & 0 & H & 0.00 & 46005 & 28884 & 71.00 & 915.21 \\
\hline GW-367 & 0 & H & 0.00 & 46695 & 28884 & 112.00 & 874.21 \\
\hline GW-367 & 0 & H & 0.00 & 46695 & 28884 & 127.00 & 85921 \\
\hline GW-368 & 0 & H & 0.00 & 47618 & 28913 & 225.00 & 773.63 \\
\hline GW-534 & 1 & $v$ & . & 49492 & 30393 & 21.00 & 976.43 \\
\hline GW-534 & 1 & v & 0.50 & 49492 & 30393 & 22.50 & 974.93 \\
\hline $\begin{array}{l}\text { GW-538 } \\
\text { GW-538 }\end{array}$ & $\begin{array}{l}1 \\
1\end{array}$ & $\begin{array}{l}v \\
v\end{array}$ & - & $\begin{array}{l}49379 \\
49379 \\
\end{array}$ & $\begin{array}{l}30329 \\
30329\end{array}$ & $\begin{array}{l}31.00 \\
37.50\end{array}$ & $\begin{array}{l}962.97 \\
956.47\end{array}$ \\
\hline MIN & & & 0.00 & 0 & 0 & 4.00 & 0.00 \\
\hline MAX & & & 44.00 & 69712 & 30393 & 650.00 & 101720 \\
\hline AVE & & & 1.06 & 48789 & 28113 & 94.24 & 832.19 \\
\hline STDEV & & & 338 & 14196 & 5039 & 96.69 & 180.84 \\
\hline $\mathbf{N}$ & 0 & 25 & 58.00 & 12 & 12 & 0.00 & 10.00 \\
\hline $\mathrm{T}-\mathrm{N}$ & 390 & 365 & 390 & 378 & 378 & 390 & 380 \\
\hline
\end{tabular}

$N=$ the number of missing observations

$\mathrm{T}-\mathrm{N}=$ the total number of observations minus the number of missing observations 


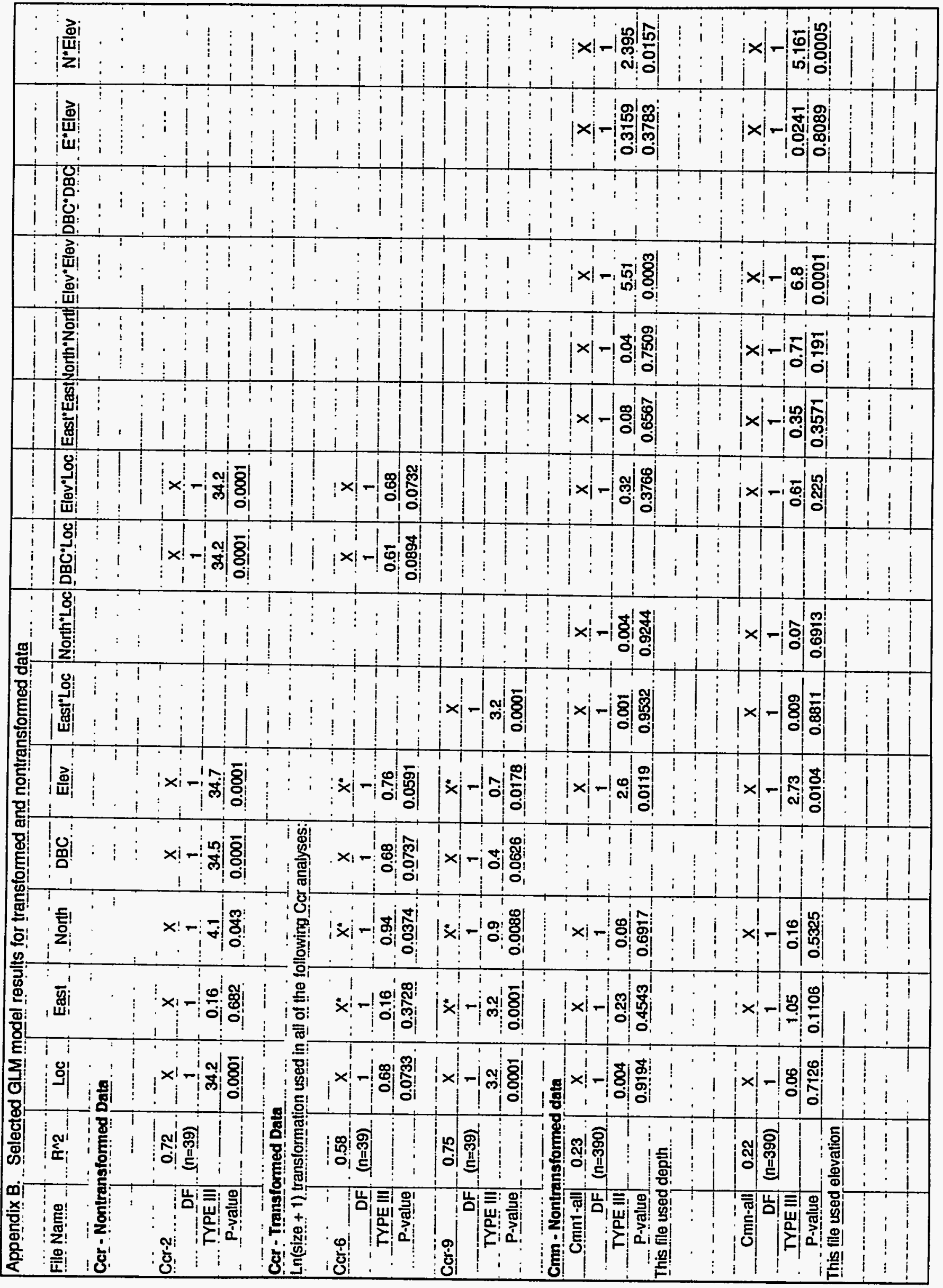




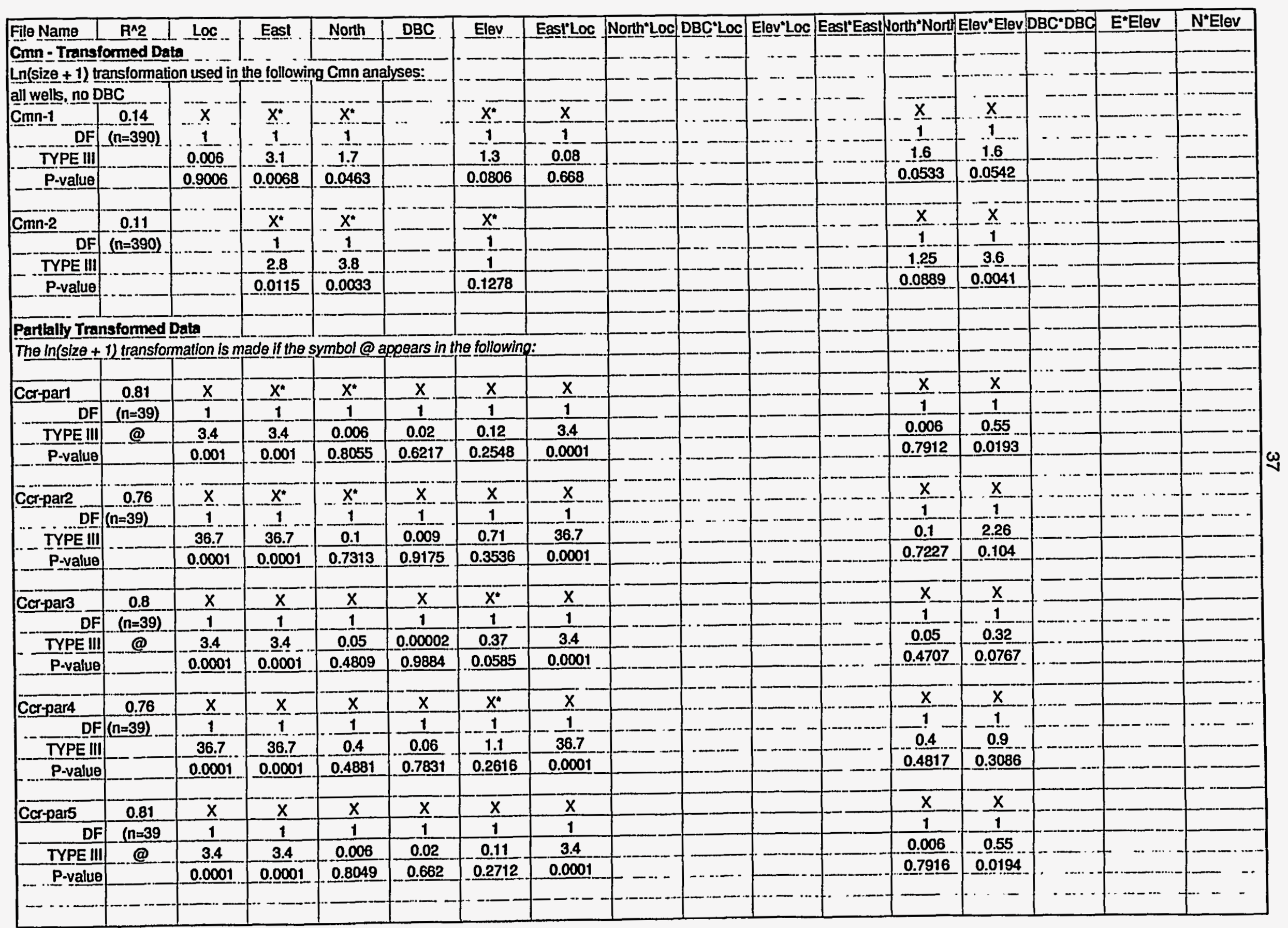




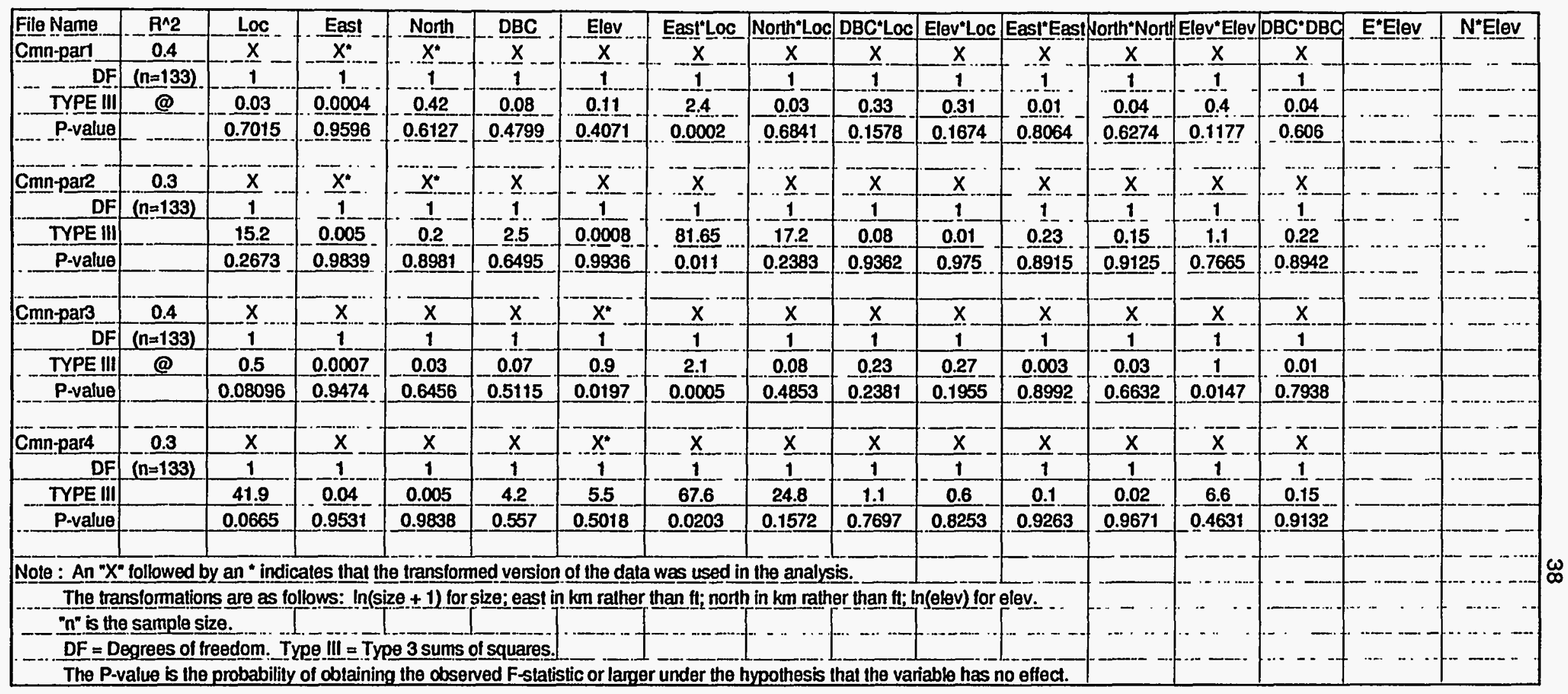




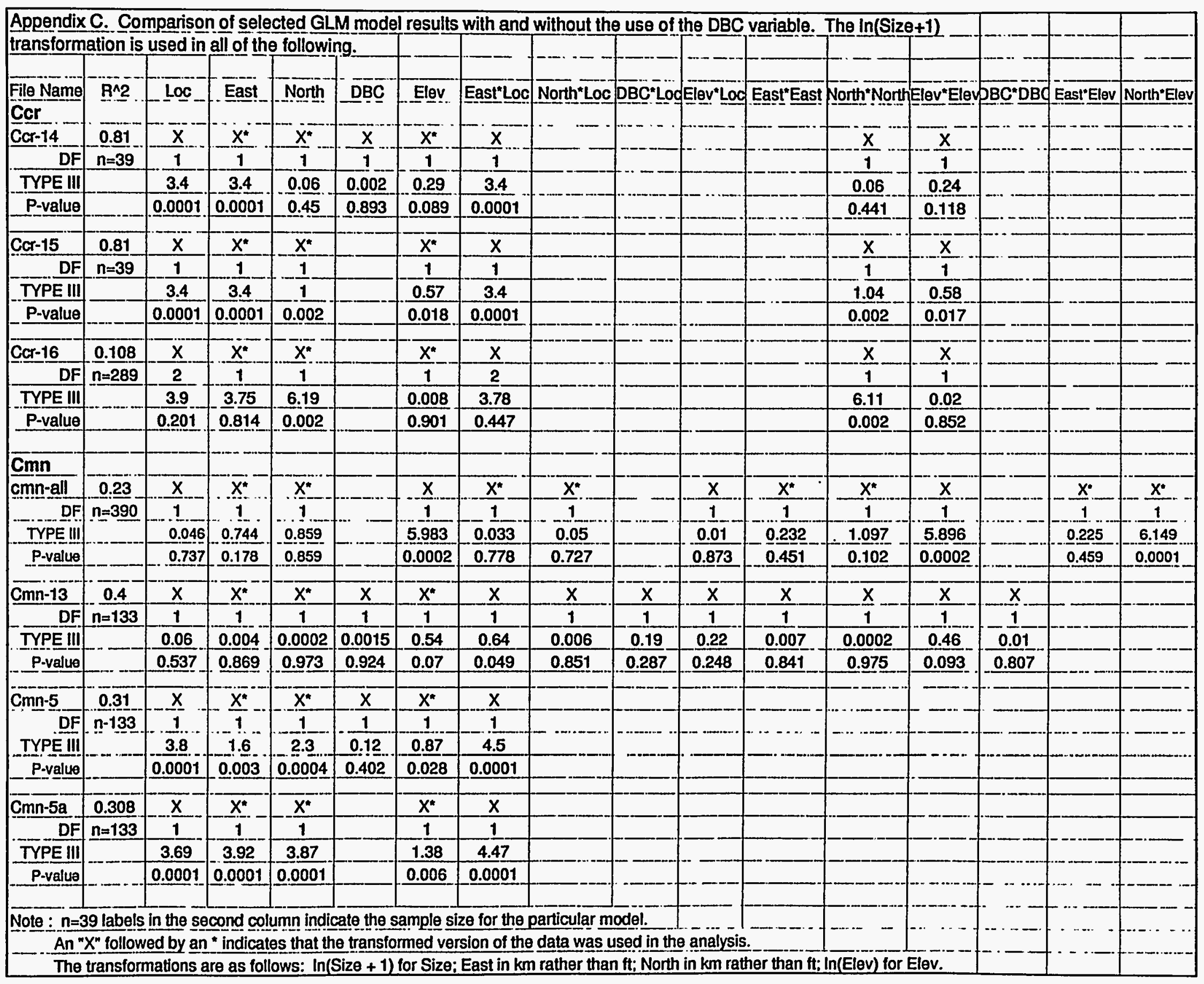




\section{0}

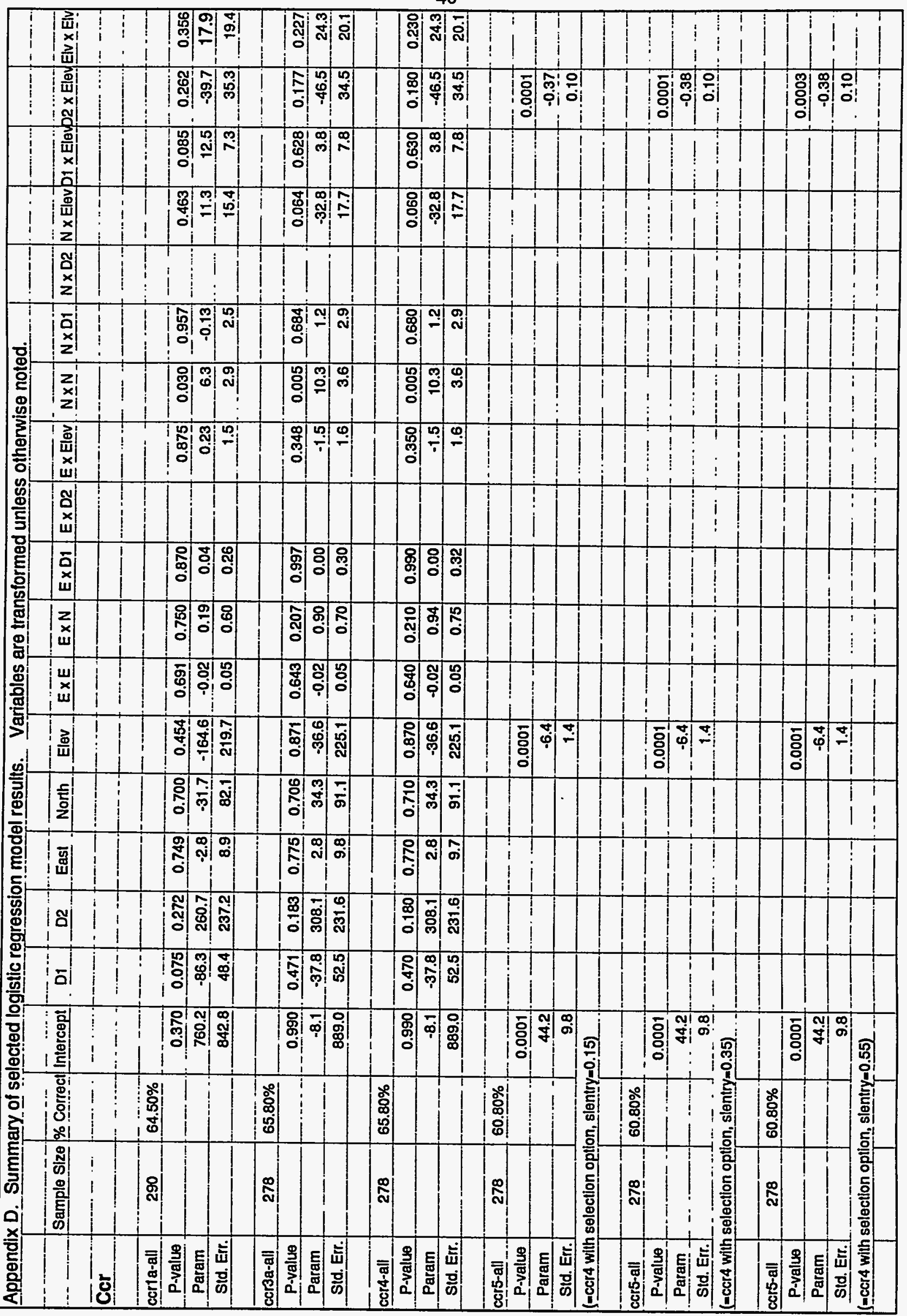


41

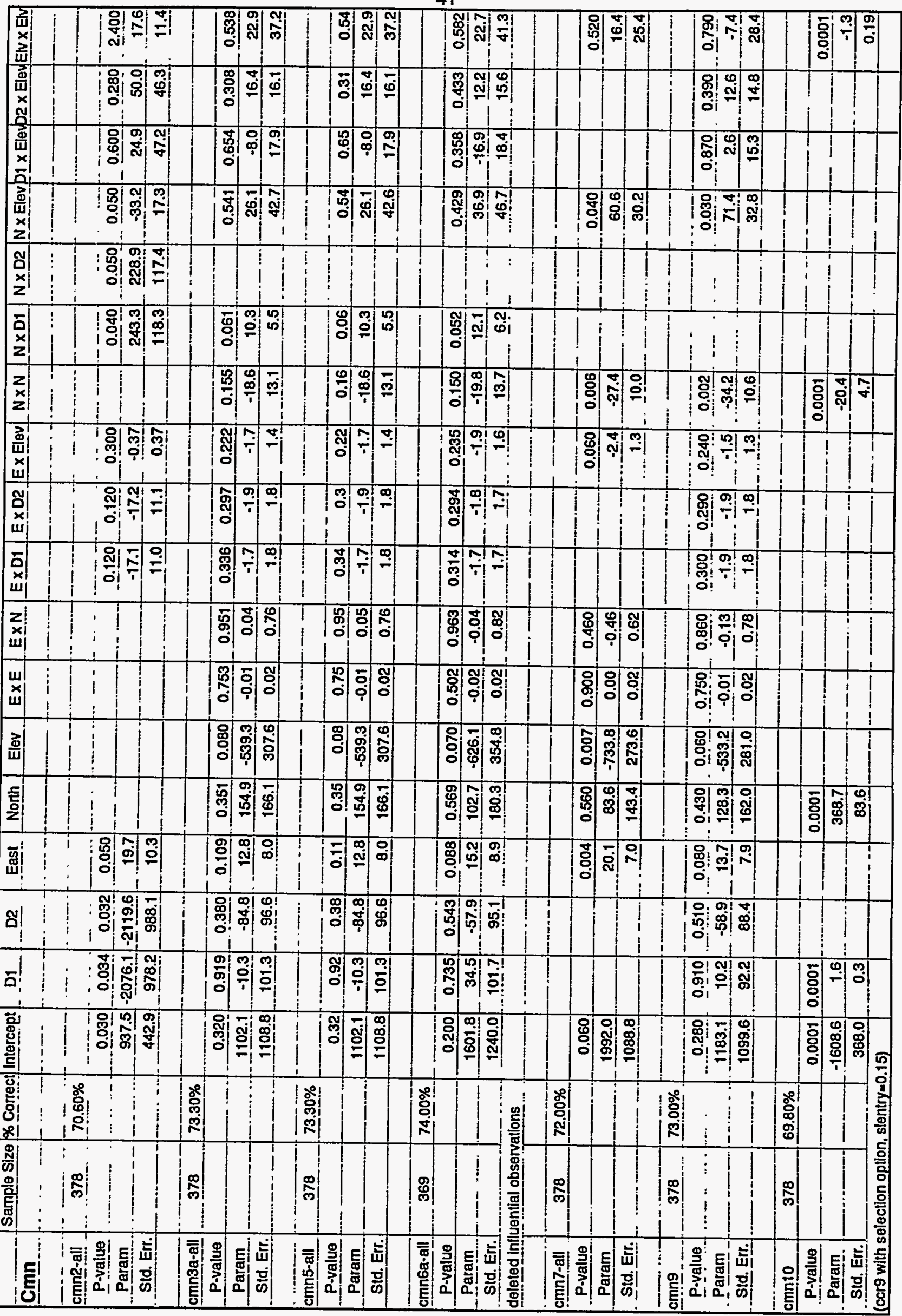




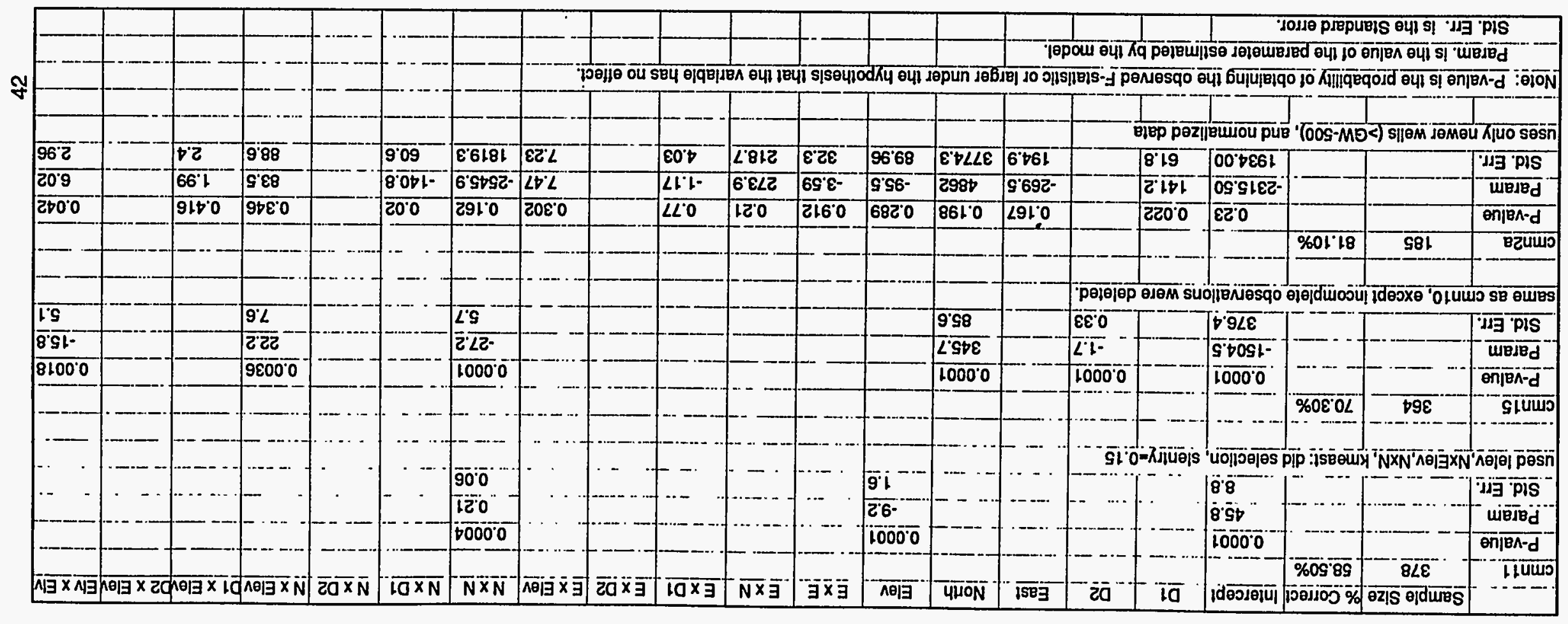




\section{DISTRIBUTION}

DEPARTMENT OF ENERGY

G. W. Bodenstein

W. G. McMillan

HEALTH. SAEETY. ENVIRONMENT, AND

ACCOUNTABILITY ORGANIZATION

W. K. Jago

S. B. Jones

S. W. Wiley

File-GWPP-RC

ENVIRONMENTAL RESTORATION PROGRAM

H. L. King (2)
ENVIRONMENTAL SCIENCES DIVISION

J. J. Beauchamp

T. O. Early

R. B. Dreier

D. D. Huff

D. B. Watson

UNIVERSITY OE NEVADA. RENO

L. A. Shevenell (3)

HSW ENVIRONMENTAL CONSULTANTS

J. R. Walker

Y-12 Central Files

CA.K-LeeIDOE-OSTI(2) 